Prepared in cooperation with the U.S. Environmental Protection Agency

\title{
Understanding Sources and Distribution of Escherichia coli at Lake St. Clair Metropark Beach, Macomb County, Michigan
}

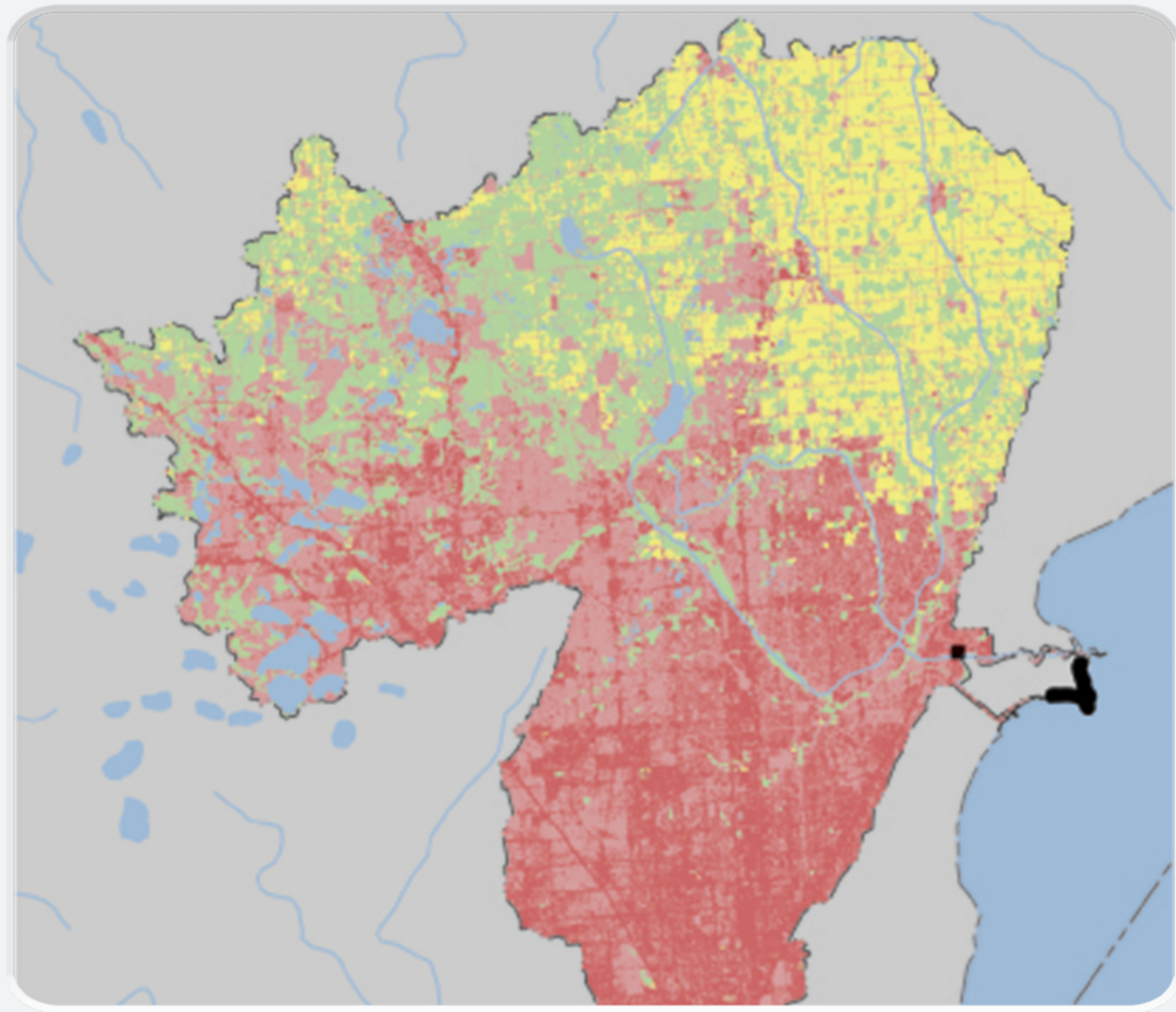

Scientific Investigations Report 2021-5089

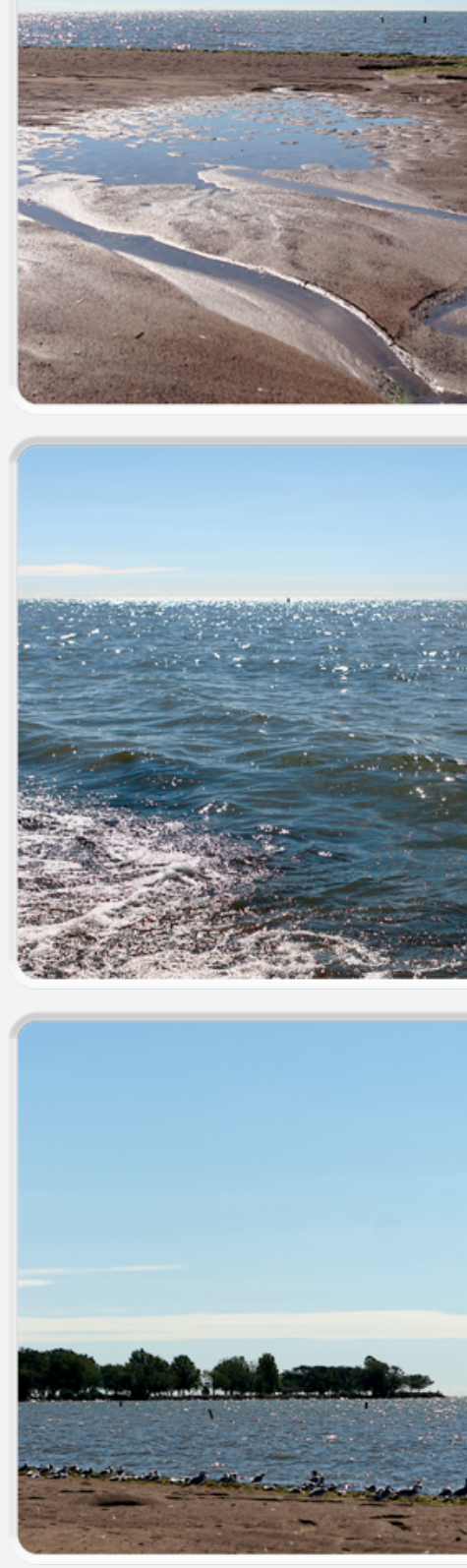




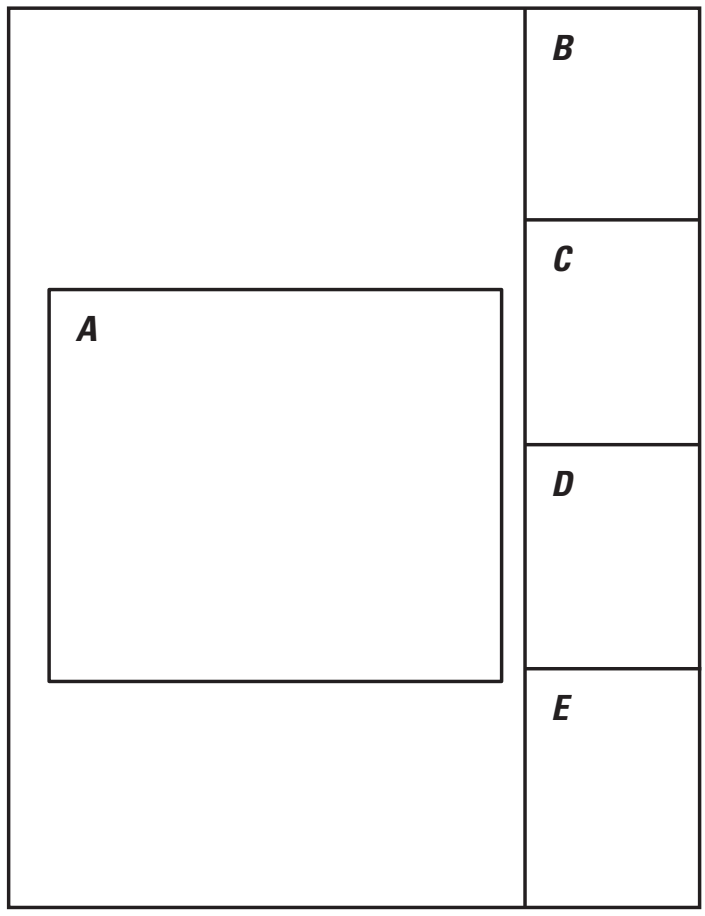

Photograph credit. $A$, modified figure 1 of this report. $B-E$, photographs by Lisa Fogarty, U.S. Geological Survey. 


\section{Understanding Sources and Distribution of Escherichia coli at Lake St. Clair Metropark Beach, Macomb County, Michigan}

By Lisa R. Fogarty, Jessica A. Maurer, Ian M. Hyslop, Alexander R. Totten, Christopher M. Kephart, Angela K. Brennan

Prepared in cooperation with the U.S. Environmental Protection Agency

Scientific Investigations Report 2021-5089 


\section{U.S. Geological Survey, Reston, Virginia: 2021}

For more information on the USGS - the Federal source for science about the Earth, its natural and living resources, natural hazards, and the environment—visit https://www.usgs.gov or call 1-888-ASK-USGS.

For an overview of USGS information products, including maps, imagery, and publications, visit https://store.usgs.gov/.

Any use of trade, firm, or product names is for descriptive purposes only and does not imply endorsement by the U.S. Government.

Although this information product, for the most part, is in the public domain, it also may contain copyrighted materials as noted in the text. Permission to reproduce copyrighted items must be secured from the copyright owner.

Suggested citation:

Fogarty, L.R., Maurer, J.A., Hyslop, I.M., Totten, A.R., Kephart, C.M., and Brennan, A.K., 2021, Understanding sources and distribution of Escherichia coli at Lake St. Clair Metropark Beach, Macomb County, Michigan: U.S. Geological Survey Scientific Investigations Report 2021-5089, 34 p., https://doi.org/10.3133/sir20215089.

Data associated with this report:

U.S. Geological Survey, 2020, USGS water data for the Nation: U.S. Geological Survey National Water Information System database, accessed May 19, 2020, at https://doi.org/10.5066/F7P55KJN.

ISSN 2328-0328 (online) 


\section{Acknowledgments}

This study was done in cooperation with the U.S. Environmental Protection Agency, Great Lakes National Program Office, with funding from the Great Lakes Restoration Initiative. Support was provided by the Clinton Area of Concern coordinators, Huron-Clinton Metroparks staff, and Macomb County Health Department. The authors gratefully acknowledge the assistance of Gregory A. Lang, National Oceanic and Atmospheric Administration, Great Lakes Environmental Research Laboratory, for providing access to the administration's weather data. We thank all the U.S. Geological Survey staff that provided technical, analytical, and editorial support for the study and this report. 



\section{Contents}

Acknowledgments ……...................................................................................................................

Abstract

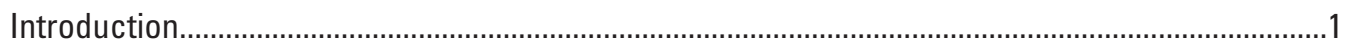

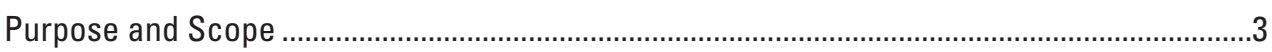

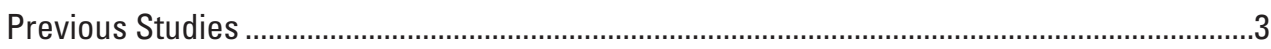

Description of the Study Area ......................................................................................

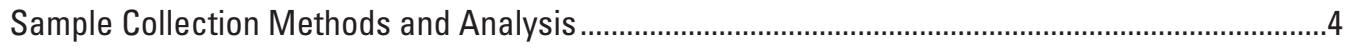

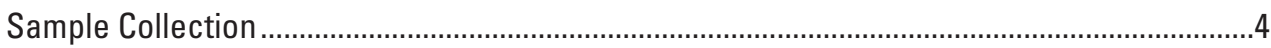

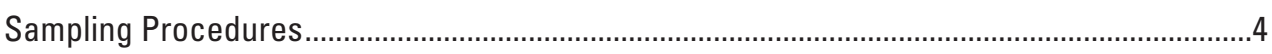

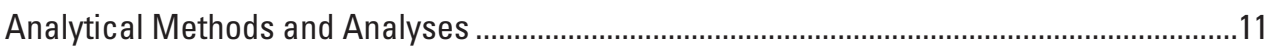

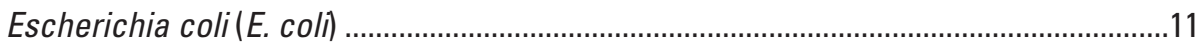

Microbial Source Tracking (MST) ..................................................................................11

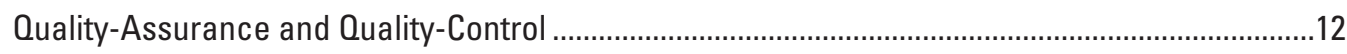

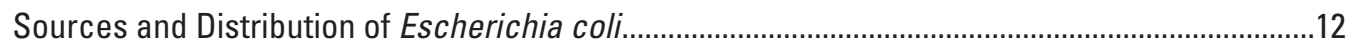

Lake St. Clair Surface Water E. coli...................................................................................13

Offshore Surface Water..............................................................................................

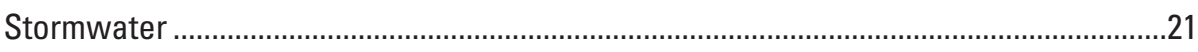

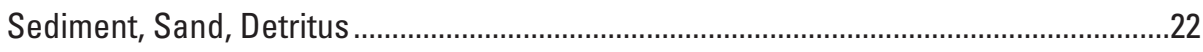

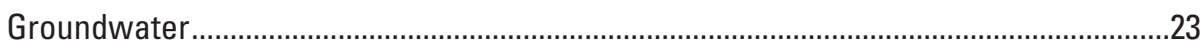

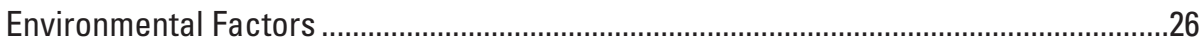

Microbial Source Tracking...........................................................................................2

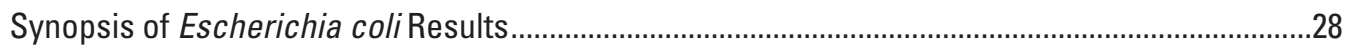

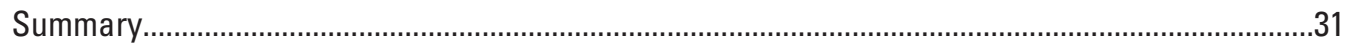

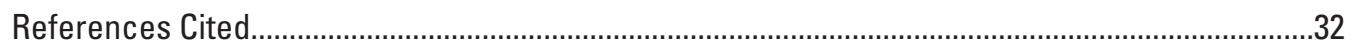

\section{Figures}

1. Map showing Clinton River drainage basin and Area of Concern boundary in Michigan .........................................................................................................................2

2. Map showing Lake St. Clair Metropark Beach study area and sampling sites.................5

3. Graph showing Escherichia coli (E. coli) concentrations from replicate samples .........13

4. Graphs showing boxplots of Escherichia coli concentrations in shallow and deep nearshore surface water...............................................................................16

5. Graph showing Escherichia coli concentrations in shallow and deep samples for the recreational area near beach and designated swimming area

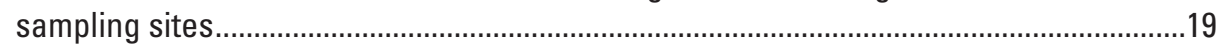

6. Graphs showing Escherichia coli concentrations and daily discharge at USGS station 04165500 by date in 2018 and 2019...................................................20

7. Graph showing daily mean discharge at the USGS streamgage 04165500 on the Clinton River at Moravian Drive at Mount Clemens, Michigan, August 1-19, 2019.........21

8. Photograph showing Lake St. Clair Metropolitan Beach from onshore showing standing water on beach draining into Lake St. Clair after a storm event on May 9, 2019 . 
9. Photograph showing Lake St. Clair Metropolitan Beach from offshore showing standing water on beach draining into Lake St. Clair after a storm event on August 1, 2018...

10. Figures showing Lake St. Clair Metropark Beach showing groundwater sampling sites and Escherichia coli concentrations on different dates in 2018-2019

11. Graph showing Escherichia coli (E. coli) concentrations for samples collected during wet and dry conditions in 2018-2019.

12. Graph showing Escherichia coli concentrations of samples with detection and nondetection of waterfowl marker in surface water and groundwater samples and human marker in groundwater

\section{Tables}

1. Summary of study sites and sampling dates for surface-water samples.........................6

2. Groundwater sampling sites and collection date .........................................................

3. Summary of study sites and sampling dates for beach sand and lake bottoms solid samples. .8

4. Summary of sites, dates, and times of detritus sample collection 10

5. Standard curve characteristics and limits of detection and quantification for microbial source tracking markers.

6. Quality-control sequential field replicate data for microbial source tracking markers

7. Summary statistics of surface-water samples analyzed for Escherichia coli concentrations in 2018 and 2019

8. Summary of exceedances of Escherichia coli concentrations compared the State of Michigan Recreational Water-Quality Criterion for total body contact for a single event

9. Descriptions of storm drain outlet samples collected along Black Creek and Escherichia coli concentrations for the Lake St. Clair Metropolitan Beach study in 2018 and 2019

10. Descriptions of standing water samples collected and Escherichia coli concentrations for the Lake St. Clair Metropolitan Beach Study in 2018 and 2019 .

11. Summary statistics of Escherichia coli concentrations in detritus and beach sand samples collected at the surface and at depth for the Lake St. Clair Metropolitan Beach study in 2018 and 2019...

12. Summary statistics of Escherichia coli concentrations in beach sand samples collected along transects at the beach for Lake St. Clair Metropolitan Beach study in 2018 and 2019

13. Summary statistics of Escherichia coli concentrations in beach sand samples collected during wet and dry conditions for Lake St. Clair Metropolitan Beach study in 2018 and 2019

14. Summary of Escherichia coli concentrations in groundwater samples for each sample collection date for the Lake St. Clair Metropolitan Beach Study in 2018 and 2019 ...

15. Correlation coefficients for Escherichia coli concentrations in relation to selected environmental variables for Lake St. Clair Metropark Beach in 2018-2019. 
16. Description of microbial source tracking results for human (HF183) and waterfowl (GFD) markers and Escherichia coli concentrations..

\section{Conversion Factors}

U.S. customary units to International System of Units

\begin{tabular}{|c|c|c|}
\hline Multiply & By & To obtain \\
\hline \multicolumn{3}{|c|}{ Length } \\
\hline inch (in.) & 2.54 & centimeter $(\mathrm{cm})$ \\
\hline inch (in.) & 25.4 & millimeter $(\mathrm{mm})$ \\
\hline foot $(\mathrm{ft})$ & 0.3048 & meter $(\mathrm{m})$ \\
\hline mile (mi) & 1.609 & kilometer $(\mathrm{km})$ \\
\hline mile, nautical (nmi) & 1.852 & kilometer $(\mathrm{km})$ \\
\hline yard (yd) & 0.9144 & meter $(\mathrm{m})$ \\
\hline \multicolumn{3}{|c|}{ Area } \\
\hline acre & 4,047 & square meter $\left(\mathrm{m}^{2}\right)$ \\
\hline square mile $\left(\mathrm{mi}^{2}\right)$ & 259.0 & hectare (ha) \\
\hline square mile $\left(\mathrm{mi}^{2}\right)$ & 2.590 & square kilometer $\left(\mathrm{km}^{2}\right)$ \\
\hline \multicolumn{3}{|c|}{ Velocity and flow rate } \\
\hline cubic foot per second $\left(\mathrm{ft}^{3} / \mathrm{s}\right)$ & 0.02832 & cubic meter per second $\left(\mathrm{m}^{3} / \mathrm{s}\right)$ \\
\hline mile per hour $(\mathrm{mi} / \mathrm{h})$ & 1.609 & kilometer per hour $(\mathrm{km} / \mathrm{h})$ \\
\hline \multicolumn{3}{|c|}{ Mass } \\
\hline ounce, avoirdupois (oz) & 28.35 & $\operatorname{gram}(\mathrm{g})$ \\
\hline
\end{tabular}

International System of Units to U.S. customary units

\begin{tabular}{lll}
\hline \multicolumn{1}{c}{ Multiply } & By & \multicolumn{1}{c}{ To obtain } \\
\hline millimeter $(\mathrm{mm})$ & Length & \\
meter $(\mathrm{m})$ & 0.03937 & inch (in.) \\
kilometer $(\mathrm{km})$ & 3.281 & foot (ft) \\
kilometer $(\mathrm{km})$ & 0.6214 & mile (mi) \\
meter $(\mathrm{m})$ & 0.5400 & mile, nautical (nmi) \\
& 1.094 & yard (yd) \\
\hline square meter $\left(\mathrm{m}^{2}\right)$ & Area & \\
\hline & 0.0002471 & acre \\
\hline gram $(\mathrm{g})$ & Mass & \\
\hline
\end{tabular}

Temperature in degrees Celsius $\left({ }^{\circ} \mathrm{C}\right)$ may be converted to degrees Fahrenheit $\left({ }^{\circ} \mathrm{F}\right)$ as follows:

$$
{ }^{\circ} \mathrm{F}=\left(1.8 \times{ }^{\circ} \mathrm{C}\right)+32 .
$$




\section{Datum}

Horizontal coordinate information is referenced to North American Datum of 1983 (NAD 83).

\section{Supplemental Information}

Specific conductance is given in microsiemens per centimeter at 25 degrees Celsius $\left(\mu \mathrm{S} / \mathrm{cm}\right.$ at $\left.25^{\circ} \mathrm{C}\right)$.

Concentrations of chemical constituents in water are given in either milligrams per liter (mg/L) or micrograms per liter $(\mu \mathrm{g} / \mathrm{L})$.

Concentrations of Escherichia coli (E. coli) in water are reported as most probable number per 100 milliliters (MPN/100 mL) or as colony-forming units per 100 milliliters (CFU/100 mL).

Microbial source tracking markers are reported as copies per 100 milliliters.

Concentrations of Escherichia coli (E. coli) in beach sand are reported as most probable number per 100 milliliters of sample water (MPN/100 mL) per gram dry weight $(\mathrm{g} \mathrm{dw})$. 


\section{Abbreviations}

$\begin{array}{ll}\text { AOC } & \text { Area of Concern } \\ \text { BRL } & \text { below reporting level } \\ \text { BUI } & \text { Beneficial Use Impairment } \\ \text { CFU } & \text { colony-forming units } \\ \text { DSA } & \text { designated swimming area } \\ \text { EPA } & \text { U.S. Environmental Protection Agency } \\ \text { E. coli } & \text { Escherichia coli } \\ \text { HECWFS } & \text { Huron to Erie Connecting Waterways Forecasting System } \\ \text { LSCMB } & \text { Lake St. Clair Metropark Beach } \\ \text { LoB } & \text { limit of blank } \\ \text { LoD } & \text { limit of detection } \\ \text { LoO } & \text { limit of quantification } \\ \text { MCHD } & \text { Macomb County Health Department } \\ \text { MIBaRL } & \text { Michigan Bacteriological Research Laboratory } \\ \text { MPN } & \text { most probable number (of bacteria) } \\ \text { MST } & \text { microbial source tracking } \\ \text { NFM } & \text { National Field Manual } \\ \text { NOAA } & \text { National Oceanic and Atmospheric Association } \\ \text { NTU } & \text { nephelometric turbidity units } \\ \text { PS } & \text { park shoreline } \\ \text { OWML } & \text { Ohio Water Microbiological Laboratory } \\ \text { USGS } & \text { U.S. Geological Survey } \\ \text { qPCR } & \text { quantitative polymerase chain reaction } \\ \text { RNB } & \text { recreational area near beach } \\ \end{array}$





\title{
Understanding Sources and Distribution of Escherichia coli at Lake St. Clair Metropark Beach, Macomb County, Michigan
}

\author{
By Lisa R. Fogarty, Jessica A. Maurer, Ian M. Hyslop, Alexander R. Totten, Christopher M. Kephart, \\ Angela K. Brennan
}

\section{Abstract}

Lake St. Clair Metropark Beach (LSCMB) in Michigan is a public beach near the mouth of the Clinton River that has a history of beach closures for public health concerns. The Clinton River is designated as a Great Lakes Area of Concern, and the park has a Beneficial Use Impairment for beach closings because of elevated Escherichia coli (E. coli) concentrations. The U.S. Geological Survey, in cooperation with the U.S. Environmental Protection Agency and in collaboration with the Michigan Department of the Environment, Great Lakes, and Energy, Macomb County Health Department, and Huron-Clinton Metroparks, completed a 2-year study to determine sources of E. coli in LSCMB. Samples were collected during dry and wet weather periods to observe the sampling sites under different conditions. Nearshore surface water samples were collected biweekly July through October in 2018 and May through September in 2019. There were 20 sampling sites along the shoreline of the park and in the channel north of the park. In addition to collecting nearshore surface-water samples, samples were collected from shallow groundwater, lake-bottom material, standing water on the beach and surrounding the recreational beach area, solids (beach sands and detritus), and offshore surface-water sites. In 2019, additional samples for microbial source tracking (MST) were collected on three dates in midsummer and were analyzed for human (HF183) and bird/waterfowl (GFD) MST markers. The concentrations of E. coli at LSCMB (in order of highest to lowest $E$. coli concentrations) were as follows: shallow groundwater nearest to the water's edge, surface sands and organic matter (detritus), standing water on the beach, nearshore surface water in and surrounding the recreational beach area, lakebottom material, and offshore surface water. The combination of low E. coli concentrations offshore and higher concentrations nearshore indicate nearshore sources, possibly from beach sands or groundwater, rather than sources coming from offshore Lake St. Clair waters. The subset of samples for MST analysis did not have enough positive results to illustrate MST trends, but this study demonstrated that both human and waterfowl sources can affect the water quality at LCSMB.

\section{Introduction}

In the 1980s, the United States and Canada identified 43 Areas of Concern (AOCs) around the Great Lakes (International Joint Commission United States and Canada, 1987). These were geographic areas that were highly degraded by one or more of 14 identified Beneficial Use Impairments (BUIs). The Great Lakes Water Quality Agreement (International Joint Commission United States and Canada, 1987, p. 24) states:

"impairment of beneficial use(s)" means a change in the chemical, physical or biological integrity of the Great Lakes System sufficient to cause any of the following:

i. restrictions on fish and wildlife consumption;

ii. tainting of fish and wildlife flavour;

iii. degradation of fish wildlife populations;

iv. fish tumors or other deformities;

v. bird or animal deformities or reproduction problems; vi. degradation of benthos;

vii. restrictions on dredging activities;

viii. eutrophication or undesirable algae;

ix. restrictions on drinking water consumption, or taste and odour problems;

$\mathrm{x}$. beach closings;

xi. degradation of aesthetics;

xii. added costs to agriculture or industry;

xiii. degradation of phytoplankton and zooplankton

populations; and

xiv. loss of fish and wildlife habitat."

Possible sources of contaminants associated with AOCs may include nonpoint urban and rural runoff, combined sewer overflows, municipal and industrial point source discharges, and contaminated sediments (Michigan Department of Natural Resources, 1988).

The Clinton River AOC includes the entire Clinton River drainage basin and nearshore areas of Lake St. Clair south of the Clinton River mouth in Michigan (fig. 1). Because of high Escherichia coli (E. coli) concentrations and frequent beach closures, the Lake St. Clair Metropark Beach (LSCMB) in Macomb County, Michigan, was included in the Clinton 


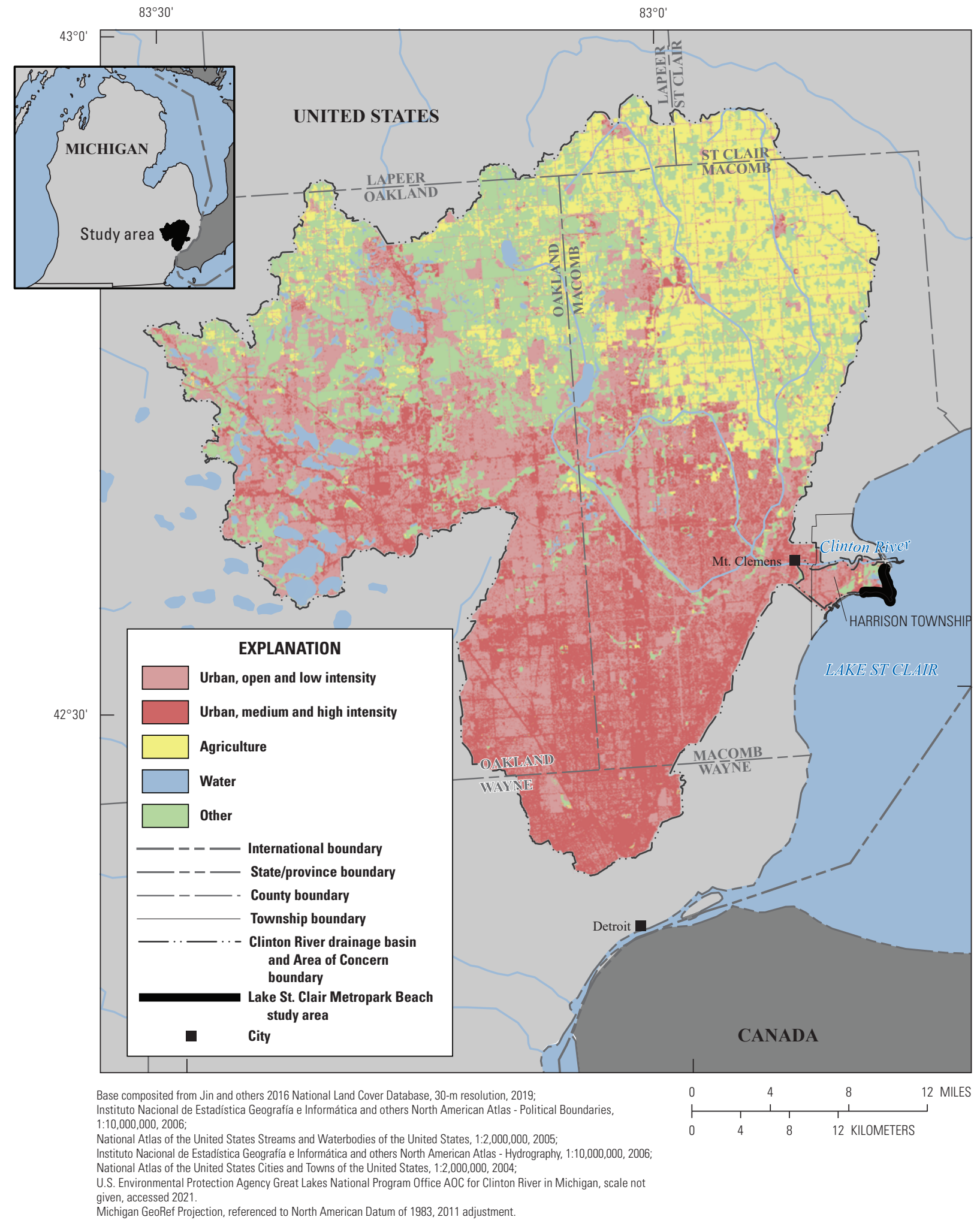

Figure 1. Clinton River drainage basin and Area of Concern boundary in Michigan, with the Lake St. Clair Metropark Beach study area. 
River AOC for the Beach Closure BUI (Michigan Department of Environmental Quality, 2009). Beach managers rely on water-quality monitoring programs to indicate the presence of fecal indicator bacteria such as enterococci and $E$. coli to make informed decisions including issuing advisories and closing beaches with the goal of reducing public health risk (U.S. Environmental Protection Agency, 2019).

$E$. coli live in the intestinal tracts of humans, other warm-blooded mammals, and birds. Most strains of E. coli do not pose a human health risk; however, E. coli can indicate the presence of other disease-causing microorganisms (pathogenic bacteria, viruses, and protozoa) that are found in fecal waste and cause waterborne disease outbreaks nationwide (U.S. Environmental Protection Agency, 2012). The U.S. Environmental Protection Agency (EPA) has established guidelines for Recreational Water-Quality Criteria based on human health risk studies (U.S. Environmental Protection Agency, 2012). The State of Michigan has established state water-quality criteria based on the EPA guidelines (Michigan Department of Environmental Quality, 2006, p. 55) as follows:

"R 323.1062 Microorganisms Rule 62(1): All waters of the state protected for total body contact recreation shall not contain more than 130 E. coli per 100 milliliters ( $\mathrm{ml})$, as a 30-day geometric mean. Compliance shall be based on the geometric mean of all individual samples taken during 5 or more sampling events representatively spread over a 30-day period. Each sampling event shall consist of 3 or more samples taken at representative locations within a defined sampling area. At no time shall the waters of the state protected for total body contact recreation contain more than a maximum of 300 E. coli per $100 \mathrm{ml}$. Compliance shall be based on the geometric mean of 3 or more samples taken during the same sampling event at representative locations within a defined sampling area."

Since 2000, LSCMB has been closed for 187 days, ranging from 0 to 47 beach closure days in a single year (Michigan Department of Environmental Quality, 2020). The monitoring season typically starts between May 1 and May 31 and continues through September 30 each year, with 122 to 152 beach days a year depending on the start date.

Sources of contamination resulting in beach closures at LSCMB are undetermined. Microbial source tracking (MST) refers to a group of analytical tools used to characterize sources of fecal contamination that can inform management agencies and enable them to implement source-appropriate remediation strategies to improve water quality (Boehm and others, 2003; Francy and others, 2005; U.S. Environmental Protection Agency, 2005; Francy and others, 2006). MST tools are based on the concept that the gastrointestinal systems of warm-blooded animals have different selective pressures that select for specific microbial populations, such as diet or physiological differences. Standard methods have not been developed for MST, but fecal microbial populations are often characterized through detection and quantification of genetic sequences (MST markers) that are unique to the host animals. Host-associated MST markers have been identified in many warmblooded mammals such as humans and waterfowl/shorebirds (Francy and others, 2006; Hagedorn and others, 2011). MST markers can thus indicate the originating fecal source, but it is also important to understand the different pathways transporting indicators and contamination. The identified potential contaminant sources and pathways to the LSCMB may include (but are not limited to): (1) the Clinton River; (2) the Clinton River Spillway; (3) storm drain infiltration and groundwater flow to the beach; (4) unnamed channel that drains wetland and residential area at the west end of the park; (5) Lake St. Clair bottom material/sediment (beach sand); and (6) waterfowl, including Larus spp. (gulls) and Branta canadensis (Canada geese).

\section{Purpose and Scope}

From 2018 to 2019, the U.S. Geological Survey (USGS) cooperated with the EPA to determine likely sources of $E$. coli to LSCMB with the goal of reducing the number of beach closures by informing future beach restoration and mitigation efforts. This report documents E. coli concentrations at LCSMB in Macomb County, Mich., from 2018 to 2019. This study was designed to determine if the source(s) of E. coli are coming from the offshore waters of Lake St. Clair or localized sources near the recreational areas of LSCMB. Results of this study can be used to help determine status and management options to ultimately remove the beach closure BUI for the Clinton River AOC.

\section{Previous Studies}

Macomb County Health Department (MCHD) has led recreational beach water quality monitoring at LSCMB since 1995 (MCHD, 2020a) and the Clinton River and its tributaries since 1999 (MCHD, 2020b). Fogarty (2007) summarized E. coli data collected in the Clinton River drainage basin and at Lake St. Clair beaches as part of the health department monitoring in 2000-2005. During that study period, E. coli concentrations exceeded 1,000 colony-forming units $(\mathrm{CFU}) / 100$ milliliters ( $\mathrm{mL}$; partial body contact standard) in 16 percent of the samples analyzed.

Holtschlag and others (2008) published a twodimensional hydrodynamic model to simulate horizontal current patterns on Lake St. Clair in response to wind, flow, and water-level conditions. They simulated hypothetical particle tracks and used regression analysis to determine environmental explanatory variables for higher $E$. coli concentrations. Driven primarily by wind direction, hypothetical flow paths from the Clinton River to LSCMB are possible. Results from the logistical regression models that were developed to estimate the probability that $E$. coli concentrations would exceed 300 most probable number (MPN)/100 mL at Memorial and 
Metropark (formally called Metropolitan) Lake St. Clair beaches, determined that rainfall preceding the sampling events was positively associated with the probabilities of E. coli exceedance. Flow in the Clinton River was negatively associated with bacteria exceedances at Metropark Beach. The Holtschlag and others (2008) study was inconclusive as to if E. coli from the Clinton River affected nearby LSCMB, thereby resulting in beach closures.

\section{Description of the Study Area}

This study was completed at the Lake St. Clair Metropark Beach (LSCMB) in Harrison Township, Macomb County, Mich. (fig. 1). The park is a 938 -acre recreational area in an urban area along the western shore of Lake St. Clair (fig. 2). The park includes about 600 feet (ft) of sandy beach (LSCMB) on Lake St. Clair. The LSCMB is roughly 3.0 miles west of the mouth of the Clinton River that drains into Lake St. Clair, and it is part of the Clinton River AOC. The Clinton River, with a 760-square-mile drainage basin, meanders a total of 81.5 miles through wetland, forests, farmland, cities, and parks and drains into a suburban and more urbanized area via the mouth of the Clinton River just north of the peninsula along the eastern edge of the park (fig. 1). On the north side of the park, Black Creek (BC) flows from wetland areas in the park out to Lake St. Clair. There are storm drain outlets near the mouth of BC (fig. 2).

This study focused on samples collected from Lake St. Clair around the park and in the swimming areas (table 1). Samples were collected to determine possible source areas such as deeper offshore waters (table 1) that may be affected by the Clinton River. Additional samples collected to help determine sources of $E$. coli included lake-bottom sediment, surface beach sand, beach sand at depth, shallow groundwater at the beach, storm drain outlets, and standing water on land near swimming and recreational areas after rain events.

\section{Sample Collection Methods and Analysis}

The USGS collected samples July through October 2018 and May through August 2019 in shallow and deep nearshore surface water, shallow groundwater, standing water on and surrounding the recreational beach area, storm drain outfalls, and offshore surface water in the Clinton River flow. Sampling results are available in the USGS National Water Information System database (U.S. Geological Survey, 2020) by using the USGS station numbers in table 1-4. Meteorological data were obtained from the National Oceanic and Atmospheric Administration (NOAA), Mt. Clemens Air National Guard Base (NOAA, 2020), and the NOAA Great Lakes Environmental Research Laboratory CoastWatch buoy stations CLSM4 and 45147 in Lake St. Clair (NOAA, 2020b).

\section{Sample Collection}

Twenty nearshore surface water locations were routinely (on average twice per week) sampled in 2018 and 2019 and are grouped by general location: park shoreline (PS), designated swimming area (DSA), recreational area near beach (RNB), and BC (fig. 2). In 2018, the study did not start until later in the beach season, so only 20 sets of samples were collected from July through October. In 2019, 27 sets of samples were collected May through September to represent the full beach season. Additional samples in 2018 and 2019 were collected to capture effects of rainfall. Three additional sampling trips in 2019 were made to collect offshore or groundwater samples when selected routine locations were also sampled. In addition, samples were collected from the lake-bottom sediment, standing water on the beach and surrounding the recreational beach area, beach sand at stratified depths ( $0 \mathrm{ft}, 1 \mathrm{ft}$, and $2 \mathrm{ft}$ ), detritus along the shoreline, and offshore surface water sites. Offshore sampling was completed at 10 sampling locations on August 7, 2019, during Clinton River steady streamflow conditions (daily mean discharge value of 176 cubic feet per second [ $\left[\mathrm{ft}^{3} / \mathrm{s}\right.$ ] at USGS streamgage 04165500 [USGS, 2020]) and on August 14, 2019, during Clinton River high-flow conditions (daily mean discharge value of $838 \mathrm{ft}^{3} / \mathrm{s}$ at USGS streamgage 04165500 [USGS, 2020]; 1.88 inches [in.] of rain [NOAA, 2020] within 24 to 48 hours of offshore sample collection). Additional samples for MST analysis were collected on July 2, July 23, and August 7, 13, and 14, 2019. Samples were collected during various wet (defined as more than 0.10 in. of rain within 24 hours of sampling) and dry (defined as 0.00 in. of rain within 24 hours of sampling) weather conditions.

\section{Sampling Procedures}

Samples were collected by USGS personnel in accordance with the USGS National Field Manual (USGS NFM; USGS, variously dated). Surface-water samples were collected into directional flow from nearshore and offshore sampling locations between 9 a.m. and 2 p.m. local time into 100 -mL sterile, transparent, nonfluorescing vessels. Wadeable nearshore surface water samples (sites 3 through 8 ) were collected as grab samples about $2 \mathrm{ft}$ deep and are referred to as "shallow" samples. Near the beach in waters about $5 \mathrm{ft}$, samples were collected about 2-3 ft below the surface and referred to as "deep" samples. Water samples collected from standing water on the recreational beach and surrounding grass area were collected using the grab sample technique to collect water in pooled areas. Nonwadeable nearshore surface water samples were also grab samples and were collected into the directional flow from the shore with a 10-ft extendable sample pole. Uncapped turbidity and E. coli bottles were attached to the sample pole, lowered between 2 and $3 \mathrm{ft}$ below the surface into directional flow, raised out of the water, and capped. Samples were immediately placed on ice for preservation 


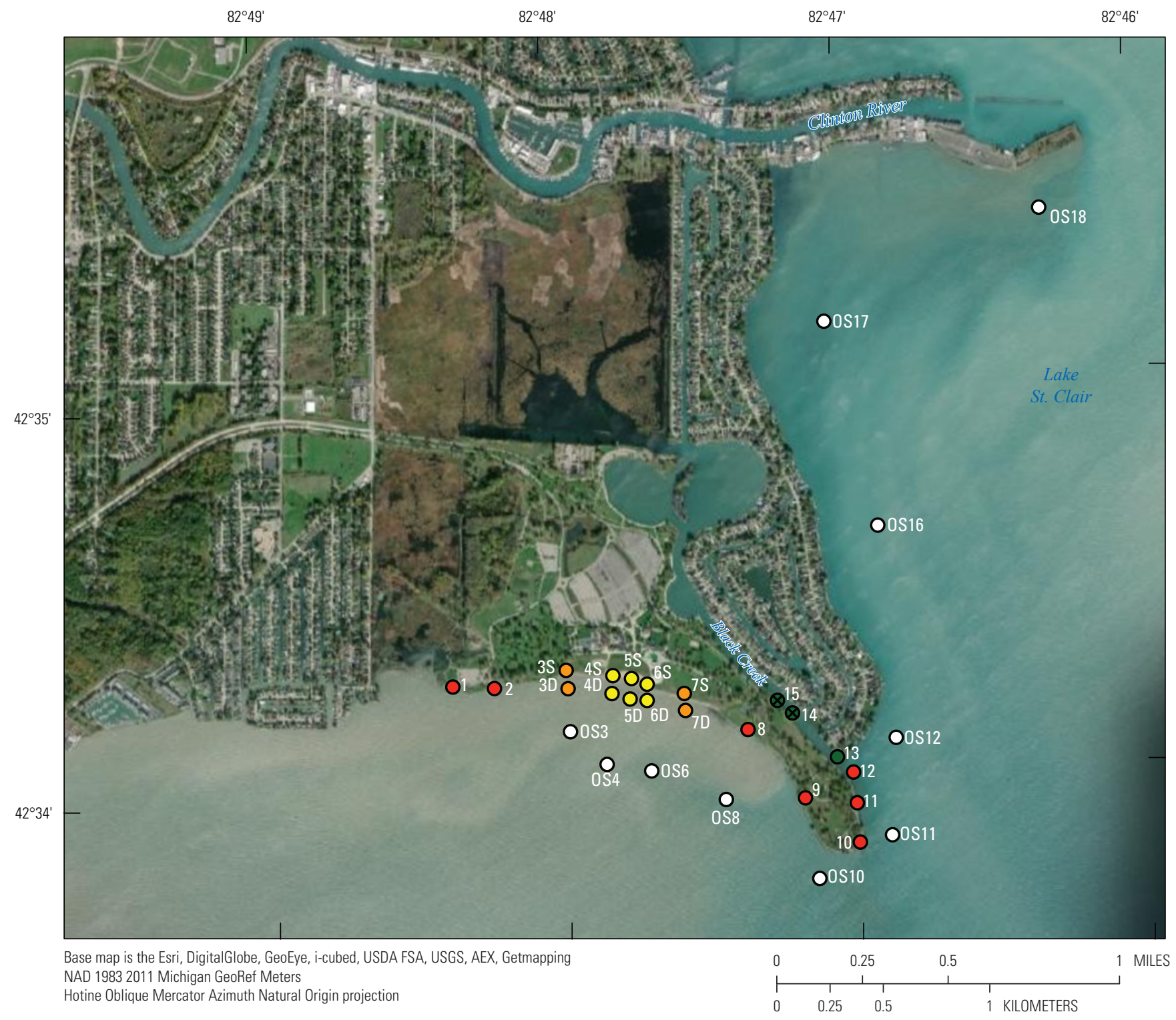

\section{EXPLANATION}

Sampling sites
- Black Creek (BC)
O Designated swimming area (DSA)
O Park shoreline (PS)
O Recreational area near beach (RNB)
O Off shore (OS)
$\otimes$ Storm drain

Figure 2. Lake St. Clair Metropark Beach study area and sampling sites. 
Table 1. Summary of study sites and sampling dates for surface-water samples.

[USGS, U.S. Geological Survey; ID, identification; LSCMB, Lake St. Clair Metropark Beach]

\begin{tabular}{|c|c|c|c|c|}
\hline General location & USGS station ID & Short ID'1 & Sampling time frame & Number of samples \\
\hline \multirow{4}{*}{$\begin{array}{l}\text { Recreational area near } \\
\text { beach (RNB), shallow }\end{array}$} & \multirow{2}{*}{423417082480001} & \multirow{2}{*}{ LSCMB-3S } & July-Oct 2018 & 20 \\
\hline & & & May-Sep 2019 & 30 \\
\hline & \multirow{2}{*}{423413082473401} & \multirow{2}{*}{ LSCMB-7S } & July-Oct 2018 & 20 \\
\hline & & & May-Sep 2019 & 28 \\
\hline \multirow{4}{*}{$\begin{array}{l}\text { Recreational area near } \\
\text { beach (RNB), deep }\end{array}$} & \multirow{2}{*}{423417082480002} & \multirow{2}{*}{ LSCMB-3D } & July-Oct 2018 & 20 \\
\hline & & & May-Sep 2019 & 30 \\
\hline & \multirow{2}{*}{423413082473402} & \multirow{2}{*}{ LSCMB-7D } & July-Oct 2018 & 20 \\
\hline & & & May-Sep 2019 & 28 \\
\hline \multirow{6}{*}{$\begin{array}{l}\text { Designated swimming area } \\
\text { (DSA), shallow }\end{array}$} & \multirow{2}{*}{423417082475001} & \multirow{2}{*}{ LSCMB-4S } & July-Oct 2018 & 20 \\
\hline & & & May-Sep 2019 & 30 \\
\hline & \multirow{2}{*}{423416082474601} & \multirow{2}{*}{ LSCMB-5S } & July-Oct 2018 & 20 \\
\hline & & & May-Sep 2019 & 28 \\
\hline & \multirow{2}{*}{423415082474201} & \multirow{2}{*}{ LSCMB-6S } & July-Oct 2018 & 20 \\
\hline & & & May-Sep 2019 & 30 \\
\hline \multirow{6}{*}{$\begin{array}{l}\text { Designated swimming area } \\
\text { (DSA), deep }\end{array}$} & \multirow{2}{*}{423417082475002} & \multirow{2}{*}{ LSCMB-4D } & July-Oct 2018 & 20 \\
\hline & & & May-Sep 2019 & 30 \\
\hline & \multirow{2}{*}{423416082474602} & \multirow{2}{*}{ LSCMB-5D } & July-Oct 2018 & 20 \\
\hline & & & May-Sep 2019 & 28 \\
\hline & \multirow{2}{*}{423415082474202} & \multirow{2}{*}{ LSCMB-6D } & July-Oct 2018 & 20 \\
\hline & & & May-Sep 2019 & 30 \\
\hline \multirow{4}{*}{$\begin{array}{l}\text { Park shoreline (PS), } \\
\text { east }\end{array}$} & \multirow{2}{*}{423416082482200} & I SCMR-1 & July-Oct 2018 & 20 \\
\hline & & LSCIVID- & May-Sep 2019 & 27 \\
\hline & 423416082481300 & I SCMB_2 & July-Oct 2018 & 20 \\
\hline & 425410002401300 & LSCAVID"- & May-Sep 2019 & 27 \\
\hline & 423408082472200 & LSCMB-8 & July-Oct 2018 & 20 \\
\hline & 425300002412200 & LSCIVID-O & May-Sep 2019 & 29 \\
\hline & 423358082471100 & L SCMB-9 & July-Oct 2018 & 20 \\
\hline & $4253000024 / 1100$ & LSC & May-Sep 2019 & 27 \\
\hline Park shoreline (PS), & 423349082470000 & L SCMB-10 & July-Oct 2018 & 20 \\
\hline west & $4250430024 / 0000$ & LSCIVID-10 & May-Sep 2019 & 29 \\
\hline & & & July-Oct 2018 & 20 \\
\hline & 423353082465900 & LSCMB-11 & May-Sep 2019 & 29 \\
\hline & & & July-Oct 2018 & 20 \\
\hline & 423358082470000 & LSCMB-12 & May-Sep 2019 & 30 \\
\hline & 423402082470500 & LSCMB-13 & July-Oct 2018 & 20 \\
\hline & & & May-Sep 2019 & 27 \\
\hline Black Creek $(\mathrm{BC})$ & 423411082471300 & L SCMB-14 & July-Oct 2018 & 20 \\
\hline 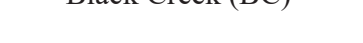 & 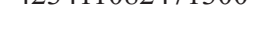 & ד & May-Sep 2019 & 27 \\
\hline & 423412082471600 & I SCMB-15 & July-Oct 2018 & 20 \\
\hline & 720712002 & Lentivets & May-Sep 2019 & 27 \\
\hline
\end{tabular}


Table 1. Summary of study sites and sampling dates for surface-water samples.-Continued

[USGS, U.S. Geological Survey; ID, identification; LSCMB, Lake St. Clair Metropark Beach]

\begin{tabular}{ccccc}
\hline General location & USGS station ID & Short ID & Sampling time frame & Number of samples \\
\hline & 423402082480301 & LSC-OS-3 & Aug 2019 & 2 \\
& 423359082475201 & LSC-OS-4 & Aug 2019 & 3 \\
& 423356082474201 & LSC-OS-6 & Aug 2019 & 2 \\
& 423351082473301 & LSC-OS-8 & Aug 2019 & 3 \\
Offshore (OS) & 423345082470301 & LSC-OS-10 & Aug 2019 & 3 \\
& 423351082465601 & LSC-OS-11 & Aug 2019 & 2 \\
& 423401082465601 & LSC-OS-12 & Aug 2019 & 2 \\
& 423431082465901 & LSC-OS-16 & Aug 2019 & 2 \\
& 423503082465401 & LSC-OS-17 & Aug 2019 & 4 \\
\hline
\end{tabular}

${ }^{1}$ Latter part of the short ID is used to identify sites on figure 2 .

Table 2. Groundwater sampling sites and collection date.

[USGS, U.S. Geological Survey; ID, identification; LSCMB, Lake St. Clair Metropark Beach; dates displayed in m/d/yyyy]

\begin{tabular}{llclccc}
\hline & & \multicolumn{5}{c}{ Sample collection date } \\
\cline { 3 - 7 } \multicolumn{1}{c}{ USGS station ID } & \multicolumn{1}{c}{ Groundwater site ID } & $\mathbf{9 / 1 1 / 2 0 1 8}$ & $\mathbf{1 0 / 1 0 / 2 0 1 8}$ & $\mathbf{6 / 1 3 / 2 0 1 9}$ & $\mathbf{7 / 2 3 / 2 0 1 9}$ & $\mathbf{8 / 1 3 / 2 0 1 9}$ \\
\hline 423417082475401 & LSCMB-3A & $\mathrm{x}$ & & & & \\
423416082474600 & LSCMB-7A & $\mathrm{x}$ & $\mathrm{x}$ & & & \\
423414082473701 & LSCMB-10A & $\mathrm{x}$ & & & & \\
423415082474301 & LSCMB-9A & $\mathrm{x}$ & $\mathrm{x}$ & & & \\
423416082474501 & LSCMB-East A & $\mathrm{x}$ & $\mathrm{x}$ & $\mathrm{x}$ & $\mathrm{x}$ & $\mathrm{x}$ \\
423416082474503 & LSCMB-East B & & $\mathrm{x}$ & $\mathrm{x}$ & $\mathrm{x}$ & $\mathrm{x}$ \\
423417082474401 & LSCMB-East C & & $\mathrm{x}$ & $\mathrm{x}$ & $\mathrm{x}$ & $\mathrm{x}$ \\
423416082474701 & LSCMB-Central A & $\mathrm{x}$ & $\mathrm{x}$ & & $\mathrm{x}$ & $\mathrm{x}$ \\
423417082474701 & LSCMB-Central B & & $\mathrm{x}$ & & $\mathrm{x}$ & $\mathrm{x}$ \\
423417082474601 & LSCMB-Central C & & $\mathrm{x}$ & & $\mathrm{x}$ & $\mathrm{x}$ \\
423416082474901 & LSCMB-West A & $\mathrm{x}$ & $\mathrm{x}$ & $\mathrm{x}$ & $\mathrm{x}$ & $\mathrm{x}$ \\
423416082474902 & LSCMB-West B & $\mathrm{x}$ & $\mathrm{x}$ & $\mathrm{x}$ & $\mathrm{x}$ & $\mathrm{x}$ \\
423417082474801 & LSCMB-West C & $\mathrm{x}$ & $\mathrm{x}$ & $\mathrm{x}$ & $\mathrm{x}$ & $\mathrm{x}$ \\
\hline
\end{tabular}


Table 3. Summary of study sites and sampling dates for beach sand and lake bottoms solid samples.

[USGS, U.S. Geological Survey; ID, identification; x, sample collected and analyzed; X, multiple samples at depth collected; dates displayed in m/d/yy]

\begin{tabular}{|c|c|c|c|c|c|c|c|c|c|}
\hline USGS station ID & 8/8/18 & $8 / 22 / 18$ & $9 / 11 / 18$ & $9 / 26 / 18$ & $10 / 10 / 18$ & $6 / 13 / 19$ & $7 / 23 / 19$ & $8 / 13 / 19$ & $8 / 26 / 19$ \\
\hline \multicolumn{10}{|c|}{ Beach sand samples } \\
\hline 423413082473404 & $\mathrm{x}$ & $\mathrm{x}$ & $\mathrm{x}$ & $\mathrm{X}$ & & & & & \\
\hline 423415082474204 & $\mathrm{x}$ & $\mathrm{x}$ & $\mathrm{x}$ & $\mathrm{X}$ & & & & & \\
\hline 423416082474501 & & & & & & $\mathrm{X}$ & $\mathrm{X}$ & $\mathrm{X}$ & $\mathrm{X}$ \\
\hline 423416082474503 & & & & & & $\mathrm{X}$ & $\mathrm{X}$ & $\mathrm{X}$ & $\mathrm{X}$ \\
\hline 423416082474504 & & $\mathrm{X}$ & $\mathrm{x}$ & $\mathrm{X}$ & $\mathrm{X}$ & & & & \\
\hline 423416082474604 & $\mathrm{x}$ & $\mathrm{x}$ & $\mathrm{x}$ & $\mathrm{X}$ & $\mathrm{X}$ & & & & \\
\hline 423416082474605 & & & & $\mathrm{X}$ & $\mathrm{X}$ & & & & \\
\hline 423416082474701 & & & & & & & $\mathrm{X}$ & $\mathrm{X}$ & $\mathrm{X}$ \\
\hline 423416082474804 & & & $\mathrm{x}$ & & & & & & \\
\hline 423416082474901 & & & & & & $\mathrm{X}$ & $\mathrm{X}$ & $\mathrm{X}$ & $\mathrm{X}$ \\
\hline 423416082474902 & & & & & $\mathrm{X}$ & $\mathrm{X}$ & $\mathrm{X}$ & $\mathrm{X}$ & $\mathrm{X}$ \\
\hline 423417082474204 & & & & $\mathrm{X}$ & & & & & \\
\hline 423417082474401 & & & & & & $\mathrm{X}$ & $\mathrm{X}$ & $\mathrm{X}$ & $\mathrm{X}$ \\
\hline 423417082474504 & & $\mathrm{x}$ & $\mathrm{X}$ & $\mathrm{X}$ & $\mathrm{X}$ & & & & \\
\hline 423417082474505 & & & & $\mathrm{X}$ & $\mathrm{X}$ & & & & \\
\hline 423417082474601 & & & & & & & $\mathrm{X}$ & $\mathrm{X}$ & $\mathrm{X}$ \\
\hline 423417082474604 & & & & $\mathrm{X}$ & $\mathrm{X}$ & & & & \\
\hline 423417082474701 & & & & & & & $X$ & $\mathrm{X}$ & $\mathrm{X}$ \\
\hline 423417082474704 & & $\mathrm{x}$ & $\mathrm{x}$ & & & & & & \\
\hline 423417082474801 & & & & & & $X$ & $X$ & $\mathrm{X}$ & $X$ \\
\hline 423417082474804 & & & & $\mathrm{X}$ & & & & & \\
\hline 423417082474904 & & $\mathrm{X}$ & $\mathrm{x}$ & $\mathrm{X}$ & $\mathrm{X}$ & & & & \\
\hline 423417082474905 & & $\mathrm{x}$ & $\mathrm{x}$ & $\mathrm{X}$ & $\mathrm{X}$ & & & & \\
\hline 423417082474906 & & & & & $\mathrm{X}$ & & & & \\
\hline 423417082475004 & $\mathrm{x}$ & $\mathrm{x}$ & $\mathrm{x}$ & & & & & & \\
\hline 423417082475304 & $\mathrm{x}$ & $\mathrm{x}$ & & & & & & & \\
\hline 423419082475104 & & $\mathrm{x}$ & $\mathrm{x}$ & & & & & & \\
\hline
\end{tabular}


Table 3. Summary of study sites and sampling dates for beach sand and lake bottoms solid samples._-Continued

[USGS, U.S. Geological Survey; ID, identification; x, sample collected and analyzed; X, multiple samples at depth collected; dates displayed in m/d/yy]

\begin{tabular}{|c|c|c|c|c|c|c|c|c|c|}
\hline USGS station ID & 8/8/18 & $8 / 22 / 18$ & 9/11/18 & $9 / 26 / 18$ & $10 / 10 / 18$ & $6 / 13 / 19$ & $7 / 23 / 19$ & $8 / 13 / 19$ & $8 / 26 / 19$ \\
\hline \multicolumn{10}{|c|}{ Lake bottom samples } \\
\hline 423353082465804 & $\mathrm{x}$ & & & & & & & & \\
\hline 423359082470004 & $\mathrm{x}$ & & & & & & & & \\
\hline 423403082470404 & $\mathrm{x}$ & & & & & & & & \\
\hline 423409082472504 & $\mathrm{x}$ & & & & & & & & \\
\hline 423412082473404 & $\mathrm{x}$ & & & & & & & & \\
\hline 423414082474204 & $\mathrm{x}$ & $\mathrm{x}$ & & & & & & & \\
\hline 423414082474204 & & & $\mathrm{x}$ & & $\mathrm{x}$ & & & & \\
\hline 423414082474205 & & & & $\mathrm{x}$ & $\mathrm{x}$ & & & & \\
\hline 423414082474604 & & & & $\mathrm{x}$ & $\mathrm{x}$ & & & & \\
\hline 423415082474604 & $\mathrm{x}$ & $\mathrm{x}$ & $\mathrm{x}$ & & $\mathrm{x}$ & & & & \\
\hline 423415082475004 & & & & $\mathrm{x}$ & $\mathrm{x}$ & & & & \\
\hline 423416082475104 & $\mathrm{x}$ & $\mathrm{x}$ & & & & & & & \\
\hline 423416082475104 & & & $\mathrm{x}$ & & $\mathrm{x}$ & & & & \\
\hline \multicolumn{10}{|l|}{423416082475104} \\
\hline 423416082475404 & $\mathrm{x}$ & & & & & & & & \\
\hline 423416082481304 & $\mathrm{x}$ & & & & & & & & \\
\hline 423417082475804 & $\mathrm{x}$ & & & & & & & & \\
\hline
\end{tabular}


Table 4. Summary of sites, dates, and times of detritus sample collection.

[USGS, U.S. Geological Survey; ID, identification; dates displayed in $\mathrm{m} / \mathrm{dd} / \mathrm{yyyy}]$

\begin{tabular}{ccc}
\hline USGS station ID & Date & Time \\
\hline 423416082474501 & $6 / 13 / 2019$ & 1215 \\
423416082474501 & $7 / 23 / 2019$ & 1225 \\
423416082474501 & $8 / 13 / 2019$ & 1015 \\
423416082474501 & $8 / 26 / 2019$ & 1031 \\
\hline 423416082474701 & $7 / 23 / 2019$ & 1040 \\
423416082474701 & $8 / 13 / 2019$ & 1150 \\
423416082474701 & $8 / 26 / 2019$ & 0935 \\
\hline 423416082474901 & $6 / 13 / 2019$ & 0904 \\
423416082474901 & $7 / 23 / 2019$ & 0845 \\
423416082474901 & $8 / 13 / 2019$ & 0830 \\
423416082474901 & $8 / 26 / 2019$ & 0835 \\
\hline
\end{tabular}

and same-day processing by the Michigan Bacteriological Research Laboratory (Lansing, Michigan; MIBaRL) (Myers and others, 2014).

To evaluate conditions of Lake St. Clair waters and sources to offshore water, samples were collected farther from land and following a transect north to the Clinton River. Offshore sampling locations were selected using the Great Lakes Environmental Research Laboratory Nowcast Huron to Erie Connecting Waterways Forecasting System (HECWFS) via Google Maps (NOAA, 2019). The HECWFS simulated tracer model identified the most probable flow paths of water and particles from the Clinton River to LSCMB. Offshore surface-water samples were collected as grab samples from a boat about $3 \mathrm{ft}$ below the water surface, and deep samples were collected using a Van Dorn sampler (USGS, variously dated). Samples were immediately capped and placed on ice for preservation and same-day processing by the MIBaRL. At each nearshore and offshore sampling site, temperature, specific conductance, and $\mathrm{pH}$ were recorded using a calibrated YSI DSS or ProPlus water quality sonde (USGS variously dated). Water chemistry properties were also recorded for standing water samples when there was enough standing water to fully submerge the water quality sonde. Turbidity values at each surface-water sample location were recorded using a calibrated HACH 2100Q handheld turbidimeter with a 10 nephelometric turbidity units (NTU) primary verification standard (USGS, variously dated).

Shallow groundwater samples were collected in 2018 and 2019 (table 2). On the first trip (September 11, 2018), samples, identified as "A," were collected along the beach near the lake and land interphase at eight locations. Two additional samples were collected upgradient, perpendicular to the lake on the west side of the beach; these samples were identified as "B" (approximately $50 \mathrm{ft}$ upland) and "C" (approximately $100 \mathrm{ft}$ upland). Based on results from the September sampling event, two additional transects perpendicular to the beach ("Central" and "East") were added. On October 10, 2018, three samples (A, B, and C) were collected along each transect (West, Central, and East) and at two sites near the lake and land interphase. In 2019, the three transects (East, Central, West) were each sampled again on June 13, July 23, and August 13. Because of public safety and park regulations, piezometers were not installed, and shallow groundwater samples were collected with modifications in accordance with the USGS NFM (USGS, variously dated). A piezometer, an auger, 0.01-in. screened PVC casing, a peristaltic pump, and tubing were used to collect groundwater samples. Equipment was sterilized between sampling locations using 70-percent ethanol and sterile deionized water rinse. Sample depths were measured at each groundwater sample location using a sterilized folding engineer's ruler. Groundwater used to measure water chemistry properties and obtain samples was collected using a peristaltic pump. Water chemistry properties at each sampling depth were recorded after 2-5 minutes or when properties were stabilized in accordance with modifications to the USGS NFM (USGS, variously dated). Temperature, specific conductance, $\mathrm{pH}$, and dissolved oxygen were measured at each groundwater sampling location using a YSI DSS and (or) ProPlus water quality sonde. Collected groundwater samples were immediately capped and placed on ice for preservation and same-day processing by the MIBaRL.

Solid samples of beach sand, detritus (vegetation, algae, and debris that has accumulated on shore in the swash zone), and lake-bottom material in the recreational swimming area were collected using sterile techniques (tables 3 and 4). In 2018, solid samples were collected on multiple dates across the beach sand area, at the surface (0 ft) 1-, 2-, and 3-foot depths. Lake-bottom samples were also collected offshore in the swimming waters. In 2019, the focus was on the beach sand area. Beach samples were collected at the same locations as the groundwater sampling locations at three discrete sampling depths (surface: $0 \mathrm{ft}$; mid: $1 \mathrm{ft}$; and bottom: $2 \mathrm{ft}$ ). A $50-\mathrm{mL}$ conical tube was used to collect solid samples. While wearing nitrile gloves, the cap was removed, and care was taken to avoid touching the insides of the cap and the tube. The surface sand $(0 \mathrm{ft})$ and detritus $(0 \mathrm{ft})$ was collected by scraping the tube along the top of the beach sand and in the detritus material until the conical tube was full.

A sterilized auger was used to create a hole for collecting bottom (2-ft) and mid (1-ft) depth beach sand samples. The mid (1-ft) and bottom (2-ft) depths were measured and recorded according to the measured groundwater level and were collected ensuring no groundwater intrusion into the beach sand samples. Sample depths were measured with a folding engineer's ruler, and beach sand temperatures at each sample depth were collected using a sterilized digital thermometer. The digital thermometer used to collect beach sand temperature was checked with a calibrated National Institute of Standards and Technology digital thermometer. The $50-\mathrm{mL}$ 
conical tube was inserted into the wall of the auger hole 1 and $2 \mathrm{ft}$ below the surface. Lake-bottom material was collected using a sterile modified sediment core sampler that collected the top 2 in. of surface lakebed material. Samples were collected in a 2-in. diameter sterilized plastic containers and immediately capped and placed on ice until processing.

Relative directional flow of nearshore surface waters was recorded by attaching flagging tape to the water quality sonde at wadeable surface-water sites and to the extendable sample pole for the nonwadeable surface-water sites. This was compared to NOAA modeled conditions. Photographs were taken, and other weather- and field-related conditions were recorded, including wind direction, barometric pressure, cloud cover, water clarity, and wave height.

Surface-water, groundwater, and standing water samples for MST analysis were collected on July 23, August 7, 13, and 14,2019 , in 500- or 1000-mL sterile polypropylene bottles using previously described sterile sampling techniques. Solid samples for MST were collected on July 2, 23, and August 13, 2019 , in 50-mL conical tubes using the same sampling techniques. Solid samples collected on July 23 and August 13 were immediately capped, placed on ice and shipped overnight to the Ohio Water Microbiological Laboratory (Columbus Ohio; OWML) for processing and analysis. Fresh known-source samples from gulls and geese were also collected into $50-\mathrm{mL}$ conical tubes, capped, stored on ice, and shipped overnight to OWML for processing.

\section{Analytical Methods and Analyses}

The EPA recommends measuring enterococci and E. coli concentrations as a measure for recreational water quality (U.S. Environmental Protection Agency, 2012). This study followed EPA recommendations for E. coli and procedures used by MCHD for beach water quality monitoring (U.S. Environmental Protection Agency, 2012; MCHD, 2019).

\section{Escherichia coli (E. coli)}

Samples were analyzed for $E$. coli by the MIBaRL using the Colilert-18 Quanti-Tray/2000 method (IDEXX Laboratories, Inc.; Westbrook, Maine). The maximum detection level for this kit is $2419.6 \mathrm{MPN} / 100 \mathrm{~mL}$. Sample results with no detection are recorded as less than $(<)$ $1 \mathrm{MPN} / 100 \mathrm{~mL}$. For samples that exceeded this limit, results were reported as greater than $(>) 2,400$. Solid samples of beach sand, detritus, and lake-bottom samples were processed in accordance with Francy and Darner (1998). Approximately 3 grams of composited sediment were added to $30 \mathrm{~mL}$ of deionized water, replacing the standard $1 \mathrm{x}$ phosphate buffered saline (often referred to as "PBS") commonly used. PBS buffering interferes with the enzyme substrate buffer already present in the Colilert-18 reagent. Samples were then diluted to $1: 100$ and 1:1000 to achieve a representative range of results.

\section{Microbial Source Tracking (MST)}

Water samples were processed immediately after receipt by OWML and solid samples were stored at $-20^{\circ} \mathrm{C}$ until subsequent analysis within 2 months. Three aliquots of each water sample were filtered through a 0.4 -micrometer, 47 -millimeter polycarbonate filter (Whatman; Florham Park, N.J.). Filters were then folded aseptically and placed into $2-\mathrm{mL}$ screw cap vials containing 0.3 gram of acid-washed glass beads (SigmaAldrich Corp.; St. Louis, Mo.). Negative controls (filter blanks) were filtered each day that samples were processed using sterile buffered water. Filtered samples were then stored at $-70{ }^{\circ} \mathrm{C}$ until subsequent analysis within a few months.

Solid samples required additional processing prior to filtration and preservation (Francy and Darner, 1998). Solid samples were removed from the $-20^{\circ} \mathrm{C}$ freezer and allowed to thaw at room temperature. Twenty grams of aseptically mixed solid were placed into a bottle containing $200 \mathrm{~mL}$ of sterile phosphate buffer. The solid/buffer mixture was shaken for 45 minutes on a wrist-action shaker, allowed to settle for 30 seconds, and then the liquid phase was poured into another sterile bottle and the remaining solid was discarded. The liquid phase of these samples was then filtered and preserved as described for water samples. Because concentrations of MST markers in solid samples were reported as copies per gram of dry weight (copies/g dw), the percent dry weight and sediment (solid) displacement factor for each sample were established based on methods described in Francy and Darner (1998). Sample DNA was extracted using DNA-EZ extraction kits from GeneRite (North Brunswick, N.J.). The extraction was done according to the manufacturer's instructions, except that no prefilter was used. Negative extraction controls (extraction blanks), consisting of a 2-mL vial containing only acid-washed glass beads, were processed with each batch of extractions. All DNA extracts were stored at $4{ }^{\circ} \mathrm{C}$ until subsequent analysis by quantitative polymerase chain reaction (qPCR) within 5 days of extraction.

Sample extracts were analyzed by qPCR for two MST markers: a human-associated Bacteroides marker (HF183; Green and others, 2014) and a waterfowl-associated Helicobacter marker (GFD; Green and others, 2012). All qPCR analyses were completed using either an Applied Biosystems StepOne Plus or QuantStudio 3 real-time PCR system (Applied Biosystems; Foster City, Calif.). All samples were analyzed in duplicate. Several no-template controls (qPCR blanks) consisting of molecular-grade sterile water instead of DNA extract were included on each qPCR plate in duplicate. For all samples, matrix inhibition was tested using matrix spikes, and results from diluted samples were used if inhibition was detected (Francy and others, 2017).

Standard curves were generated using plasmids containing the sequences for each of the targeted MST marker genes (Francy and Stelzer, 2012). Each qPCR run included a seven-point standard curve run in duplicate. Standard curve characteristics are listed in table 5. Amplification efficiency is calculated from the slope of the log-linear part of the standard 
Table 5. Standard curve characteristics and limits of detection and quantification for microbial source tracking markers.

[MST, microbial source tracking; $\mathrm{R}^{2}$, coefficient of determination; qPCR, quantitative polymerase chain reaction; HF183, human-associated Bacteroides marker; GFD, waterfowl-associated Helicobacter marker; LoB, limit of blanks]

\begin{tabular}{cccccc}
\hline $\begin{array}{c}\text { MST } \\
\text { marker }\end{array}$ & $\begin{array}{c}\text { Number of standard } \\
\text { curves run }\end{array}$ & $\begin{array}{c}\text { Mean amplification } \\
\text { efficiency (percent) }\end{array}$ & $\begin{array}{c}\text { Mean } \mathbf{R}^{\mathbf{2}} \\
\text { value }\end{array}$ & $\begin{array}{c}\text { Limit of detection } \\
\text { (copies/qPCR reaction) }\end{array}$ & $\begin{array}{c}\text { Limit of quantification } \\
\text { (copies/qPCR reaction) }\end{array}$ \\
\hline HF183 & 7 & 101 & 0.998 & 14 (6 curves) or 17 (LoB used for 1 curve) & 51 \\
GFD & 7 & 95 & 0.999 & 27 & 67 \\
\hline
\end{tabular}

curve, specifically, PCR efficiency is equal to 10-1/slope-1 (Bustin and others, 2009). Conversion of qPCR output to MST marker concentrations was done by interpolating from these standard curves.

Limit of blank (LoB), limit of detection (LoD), and limit of quantification (LoQ) were determined for each assay to describe the lowest concentration of each MST marker that can be differentiated from blank sample results, reliably detected, and quantified, respectively (Francy and others, 2017). The LoB is the lowest concentration that can be reported (with 95-percent confidence) to be greater than the concentration of the blanks. The LoB was determined for each qPCR run from results of negative filtration controls, negative extraction controls, and no-template controls. The LoB was not used to report results unless it was greater than the LoD. If $\mathrm{LoB}$ was greater than the $\mathrm{LoD}$, the $\mathrm{LoB}$ replaced the LoD. The LoD is the lowest concentration of a marker that can be detected, with 95-percent confidence and distinguishable from the blank sample results. The LoD was determined by analyzing at least 10 replicates each of several dilutions of a positive control. The LoQ is the lowest concentration of each MST marker that can be accurately quantified and is calculated from the standard deviation of the LoD replicates. If a sample result was less than the LoQ but greater than the LoD, the result was qualified as an estimate. If the MST marker was not detected in a sample or if the concentration was less than the $\mathrm{LoD}$, then results were reported as less than the sample reporting limit. The sample reporting limit is specific to each sample and is calculated using the LoD, taking into account the dilution analyzed and the initial sample volume filtered. The LoD and LoQ for each MST assay are listed in table 5.

\section{Quality-Assurance and Quality-Control}

From July to October 2018 and from May to August 2019, blank and replicate samples were collected for quality control to determine bias and variability (Myers, 2014). Thirty-eight field blank samples (approximately 3 percent of the total number of samples analyzed) were collected for this study. Ninety-three sequential replicates ( 7 percent of the total number of samples analyzed) were collected for all sample types. Of these 93 sequential replicates, 62 were surface water, 8 were groundwater, 1 was lake-bottom material, and 22 were solid samples.

E. coli was not detected in any blanks collected from surface water, groundwater, and sand/sediment. Therefore, little to no bias from outside contamination is expected to affect samples results. Replicate results are shown in figure 3. For most replicate pairs, results were typically in the same order of magnitude; however, on occasion, sample replicates varied as much as 2 orders of magnitude. Out of the 93 replicate pairs, 7 pairs had percent difference (the difference between the two values, divide by their average of the two values, multiplied by $100)$ greater than 100 . This potential variability warrants consideration when evaluating individual $E$. coli sample results.

A total of 12 field sequential replicates were collected from several sites and analyzed for MST markers for this study (table 6). The HF183 (human) MST marker was not detected above the limit of detection (LoD) for 10 of the 12 replicate pairs. For 1 replicate pair, HF183 was not detected above the LoD in the environmental sample, but the replicate sample was detected at a concentration of 2,800 copies/g dw. For another replicate pair, HF183 was detected at a concentration of 1,800 and 2,5000 copies $/ 100 \mathrm{~mL}$ in the environmental and replicate samples, respectively, resulting in an absolute value $\log$ difference of 0.04 . The GFD (waterfowl) MST marker was not detected above the LoD for 8 of the 12 replicate pairs. For 2 replicate pairs, GFD was not detected above the LoD in 1 of the 2 samples yet was detected at 2,400 copies per $100 \mathrm{~mL}$ and 220 copies/g dw for the paired samples. For the remaining 2 replicate pairs, GFD was detected at similar concentrations with absolute value log differences of 0.08 and 0.07 .

\section{Sources and Distribution of Escherichia coli}

Surface-water samples were collected at locations spanning Lake St. Clair Metropark Park (fig. 2). The designated swimming area (DSA) includes LSCMB sites 4-6 (shallow and deep swimming waters), with adjacent recreational area near the beach sites (RNB) LSCMB sites 3 and 7 (shallow and deep waters) (table 1). Samples were also collected around 
the PS, LSCMB sites 1-2 and sites 8-12; and BC, LSCMB sites 13-15 (table 1). To understand potential for nearshore sources of $E$. coli, samples were also collected from beach sand, lake bottom, and groundwater. Sampling results are available in the USGS National Water Information System database (USGS, 2020) by using the USGS station numbers in tables 1-4.

\section{Lake St. Clair Surface Water E. coli}

E. coli concentrations were typically highest in the shallow Lake St. Clair waters in and near the swimming and beach area for the park (table 7; fig. 4). The swimming and recreational deeper water samples were typically lower than their shallow counterparts. Samples collected from Lake St. Clair PS on the east and west ends of the park were generally lower than DSA or RNB, with lowest concentrations in BC samples (table 7; fig. 4).

The State of Michigan Recreational WaterQuality Criterion for total body contact for a single event (sampling date) is $300 \mathrm{CFU} / 100 \mathrm{~mL}$ (or $300 \mathrm{MPN} / 100 \mathrm{~mL}$ ), and is based on a geometric mean of three samples (Michigan Department of Environmental Quality, 2006). For this study, only one sample was collected at each location per trip, but $300 \mathrm{MPN} / 100 \mathrm{~mL}$ is used as threshold to evaluate results. Out of 971 surface water samples collected during the study period, nearly 9 percent $(n=87)$ of the samples exceeded the water quality criterion (table 8). This threshold was

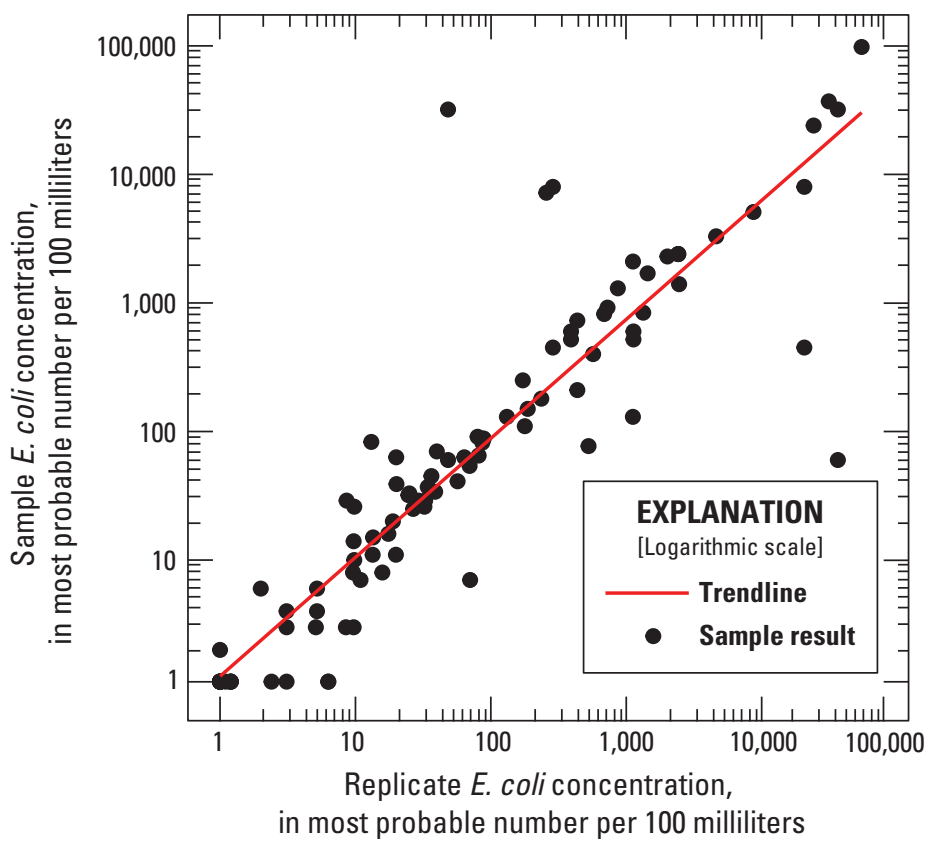

Figure 3. Escherichia coli (E. coli) concentrations from replicate samples, logarithmic scale.

exceeded most frequently in the shallow samples at the DSA and RNB, followed by the deeper water samples from DSA and RNB, then PS, and the lowest percentage of exceedance was measured at sites along BC.

Table 6. Quality-control sequential field replicate data for microbial source tracking markers, Lake St. Clair Metropark Beach, Macomb County, Michigan.

[AVLD is absolute value $\log _{10}$ difference between replicates A and B; microbial source tracking markers are reported in copies per 100 milliliters for water samples and copies per gram dry weight for solid samples; solid samples are shaded; HF183, human-associated Bacteroides marker; GFD, waterfowl-associated Helicobacter marker; BDL, result was below the limit of detection; --, no result; dates displayed in m/d/yyyy]

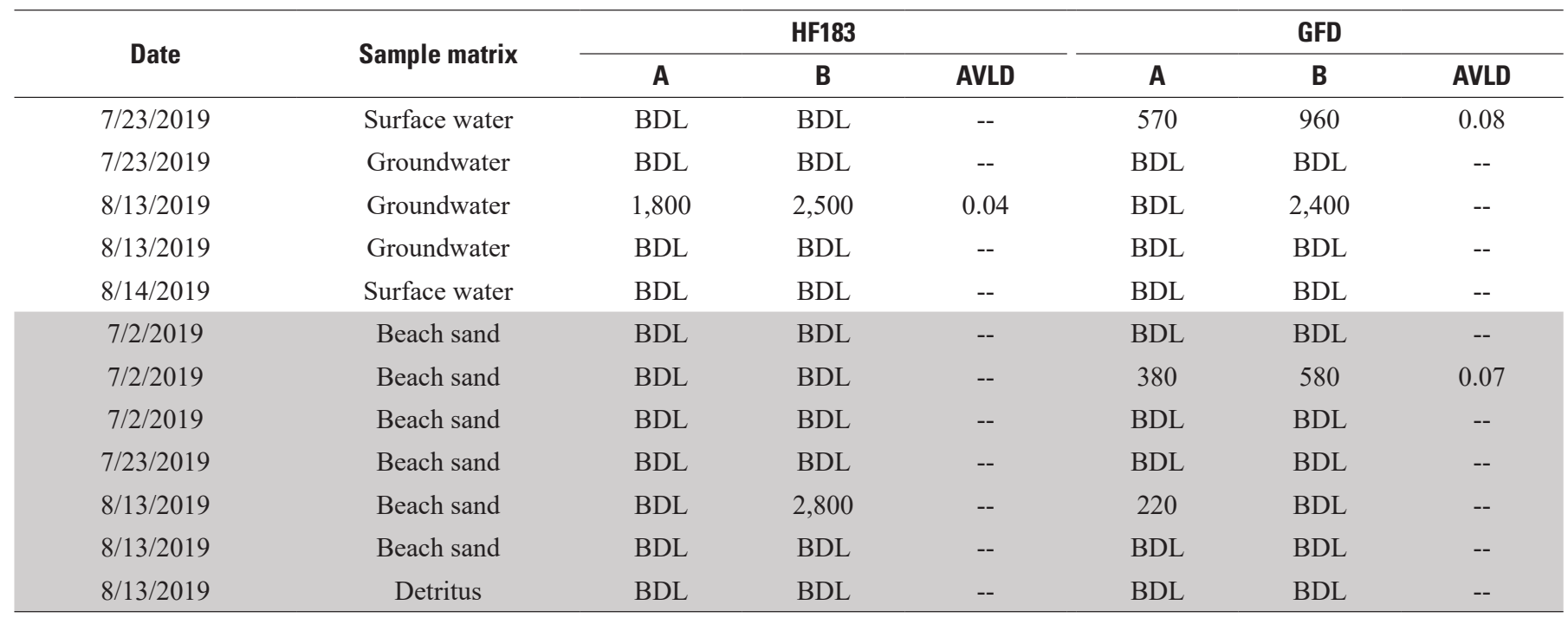


Table 7. Summary statistics of surface-water samples analyzed for Escherichia coli concentrations for the Lake St. Clair Metropark Beach study in 2018 and 2019.

[ID, identification; MPN, most probable number; mL, milliliter; LSCMB, Lake St. Clair Metropark Beach; <, less than; >, greater than]

\begin{tabular}{|c|c|c|c|c|c|c|c|}
\hline Sample location & Site ID & Sample time frame & $\begin{array}{l}\text { Number of } \\
\text { samples }\end{array}$ & Minimum & Median & Maximum & $\begin{array}{l}\text { Number of sam- } \\
\text { ples greater than } \\
300 \mathrm{MPN} / 100 \mathrm{~mL}\end{array}$ \\
\hline \multirow{4}{*}{ Park shoreline (PS) } & \multirow{2}{*}{ LSCMB-1 } & July-Oct 2018 & 20 & 1.0 & 7.5 & 580 & 1 \\
\hline & & May-Sep 2019 & 27 & 1.0 & 16 & 820 & 3 \\
\hline & \multirow{2}{*}{ LSCMB-2 } & July-Oct 2018 & 20 & 1.0 & 15 & 190 & 0 \\
\hline & & May-Sep 2019 & 27 & 1.0 & 9.7 & 1,400 & 2 \\
\hline \multirow{4}{*}{$\begin{array}{l}\text { Recreational area } \\
\text { near beach }(\mathrm{RNB})\end{array}$} & \multirow{2}{*}{ LSCMB-3S } & July-Oct 2018 & 20 & 3.0 & 51 & 1,200 & 3 \\
\hline & & May-Sep 2019 & 30 & $<1.0$ & 12 & $>2,400$ & 2 \\
\hline & \multirow{2}{*}{ LSCMB-3D } & July-Oct 2018 & 20 & 1.0 & 20 & 2,000 & 2 \\
\hline & & May-Sep 2019 & 30 & 1.0 & 8.6 & $>2,400$ & 2 \\
\hline \multirow{12}{*}{$\begin{array}{l}\text { Designated swimming } \\
\text { area (DSA) }\end{array}$} & \multirow{2}{*}{ LSCMB-4S } & July-Oct 2018 & 20 & 6.3 & 87 & $>2,400$ & 4 \\
\hline & & May-Sep 2019 & 30 & 2.0 & 40 & 1,100 & 2 \\
\hline & \multirow{2}{*}{ LSCMB-4D } & July-Oct 2018 & 20 & 1.0 & 15 & 580 & 2 \\
\hline & & May-Sep 2019 & 30 & 1.0 & 31 & 980 & 2 \\
\hline & \multirow{2}{*}{ LSCMB-5S } & July-Oct 2018 & 20 & 6.3 & 110 & $>2,400$ & 7 \\
\hline & & May-Sep 2019 & 28 & $<1.0$ & 63 & 820 & 3 \\
\hline & \multirow{2}{*}{ LSCMB-5D } & July-Oct 2018 & 20 & 3.0 & 24 & 2,000 & 4 \\
\hline & & May-Sep 2019 & 28 & $<1.0$ & 24 & 650 & 2 \\
\hline & \multirow{2}{*}{ LSCMB-6S } & July-Oct 2018 & 20 & 4.1 & 87 & 1,400 & 7 \\
\hline & & May-Sep 2019 & 30 & 2.0 & 96 & $>2,400$ & 8 \\
\hline & \multirow{2}{*}{ LSCMB-6D } & July-Oct 2018 & 20 & $<1.0$ & 24 & 1,100 & 1 \\
\hline & & May-Sep 2019 & 30 & 1.0 & 39 & 520 & 2 \\
\hline \multirow{4}{*}{$\begin{array}{l}\text { Recreational area } \\
\text { near beach }(\mathrm{RNB})\end{array}$} & \multirow{2}{*}{ LSCMB-7S } & July-Oct 2018 & 20 & 2.0 & 79 & 2,400 & 6 \\
\hline & & May-Sep 2019 & 28 & 1.0 & 46 & 2,000 & 4 \\
\hline & \multirow{2}{*}{ LSCMB-7D } & July-Oct 2018 & 20 & 2.0 & 16 & 650 & 1 \\
\hline & & May-Sep 2019 & 28 & $<1.0$ & 16 & 1,200 & 3 \\
\hline
\end{tabular}


Table 7. Summary statistics of surface-water samples analyzed for Escherichia coli concentrations for the Lake St. Clair Metropark Beach study in 2018 and 2019.-Continued [ID, identification; MPN, most probable number; mL, milliliter; LSCMB, Lake St. Clair Metropark Beach; <, less than; >, greater than]

\begin{tabular}{|c|c|c|c|c|c|c|c|}
\hline Sample location & Site ID & Sample time frame & $\begin{array}{c}\text { Number of } \\
\text { samples }\end{array}$ & Minimum & Median & Maximum & $\begin{array}{l}\text { Number of sam- } \\
\text { ples greater than } \\
300 \mathrm{MPN} / 100 \mathrm{~mL}\end{array}$ \\
\hline \multirow{10}{*}{ Park shoreline (PS) } & \multirow{2}{*}{ LSCMB-8 } & July-Oct 2018 & 20 & $<1.0$ & 22 & 1,700 & 3 \\
\hline & & May-Sep 2019 & 29 & $<1.0$ & 28 & 1,500 & 6 \\
\hline & \multirow{2}{*}{ LSCMB-9 } & July-Oct 2018 & 20 & $<1.0$ & 6.2 & $>2,400$ & 2 \\
\hline & & May-Sep 2019 & 27 & 1.0 & 6.3 & 580 & 1 \\
\hline & \multirow{2}{*}{ LSCMB-10 } & July-Oct 2018 & 20 & $<1.0$ & 6.3 & 55 & 0 \\
\hline & & May-Sep 2019 & 29 & 1.0 & 5.2 & 160 & 0 \\
\hline & \multirow{2}{*}{ LSCMB-11 } & July-Oct 2018 & 20 & 1.0 & 8.0 & 62 & 0 \\
\hline & & May-Sep 2019 & 29 & $<1.0$ & 8.4 & 86 & 0 \\
\hline & \multirow{2}{*}{ LSCMB-12 } & July-Oct 2018 & 20 & 5.2 & 10 & 56 & 0 \\
\hline & & May-Sep 2019 & 30 & 2.0 & 9.7 & 40 & 0 \\
\hline \multirow{6}{*}{ Black Creek (BC) } & \multirow{2}{*}{ LSCMB-13 } & July-Oct 2018 & 20 & 5.2 & 17 & 170 & 0 \\
\hline & & May-Sep 2019 & 27 & 5.2 & 23 & 460 & 1 \\
\hline & \multirow{2}{*}{ LSCMB-14 } & July-Oct 2018 & 20 & 1.0 & 8.5 & 250 & 0 \\
\hline & & May-Sep 2019 & 27 & 2.0 & 9.8 & 280 & 0 \\
\hline & \multirow{2}{*}{ LSCMB-15 } & July-Oct 2018 & 20 & 1.0 & 6.9 & 190 & 0 \\
\hline & & May-Sep 2019 & 27 & 2.0 & 12 & 490 & 1 \\
\hline
\end{tabular}




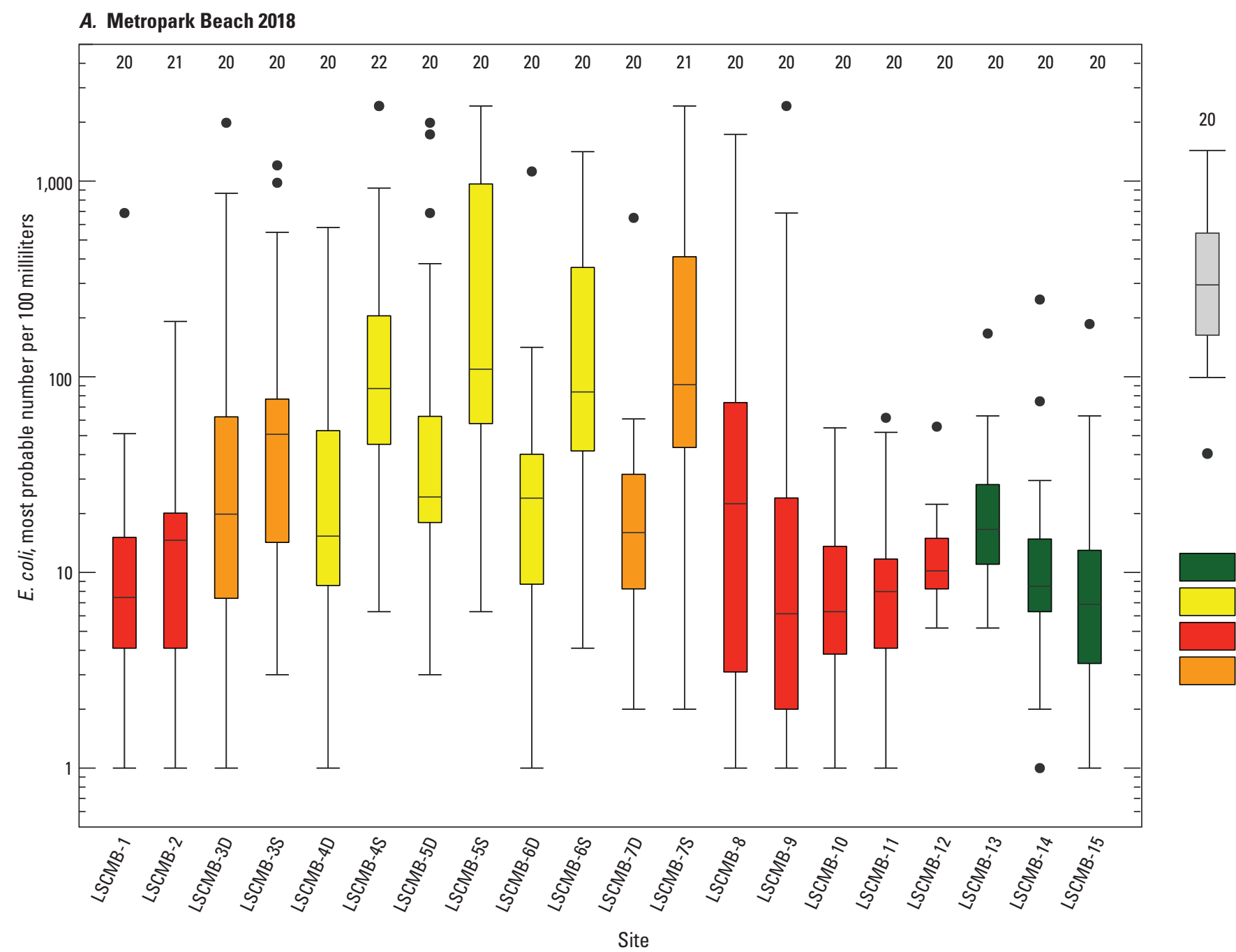

\section{EXPLANATION}

[Logarithmic scale]

Number of values

Largest value within 1.5 times

interquartile range above

75th percentile

75th percentile

50th percentile

(median)

25th percentile

Smallest value within 1.5 times interquartile range below 25th percentile

- $\quad$ Outside value-Value is $>1.5$ times and $<3$ times the interquartile range beyond either end of the box

\section{Sampling sites}

Black Creek (BC)

Designated swimming area (DSA)

Park shoreline (PS)

Recreational area near beach (RNB)

Figure 4. Boxplots of Escherichia coli (E. coli) concentrations in $\log _{10}$ scale in shallow and deep nearshore surface water. 
B. Metropark Beach 2019

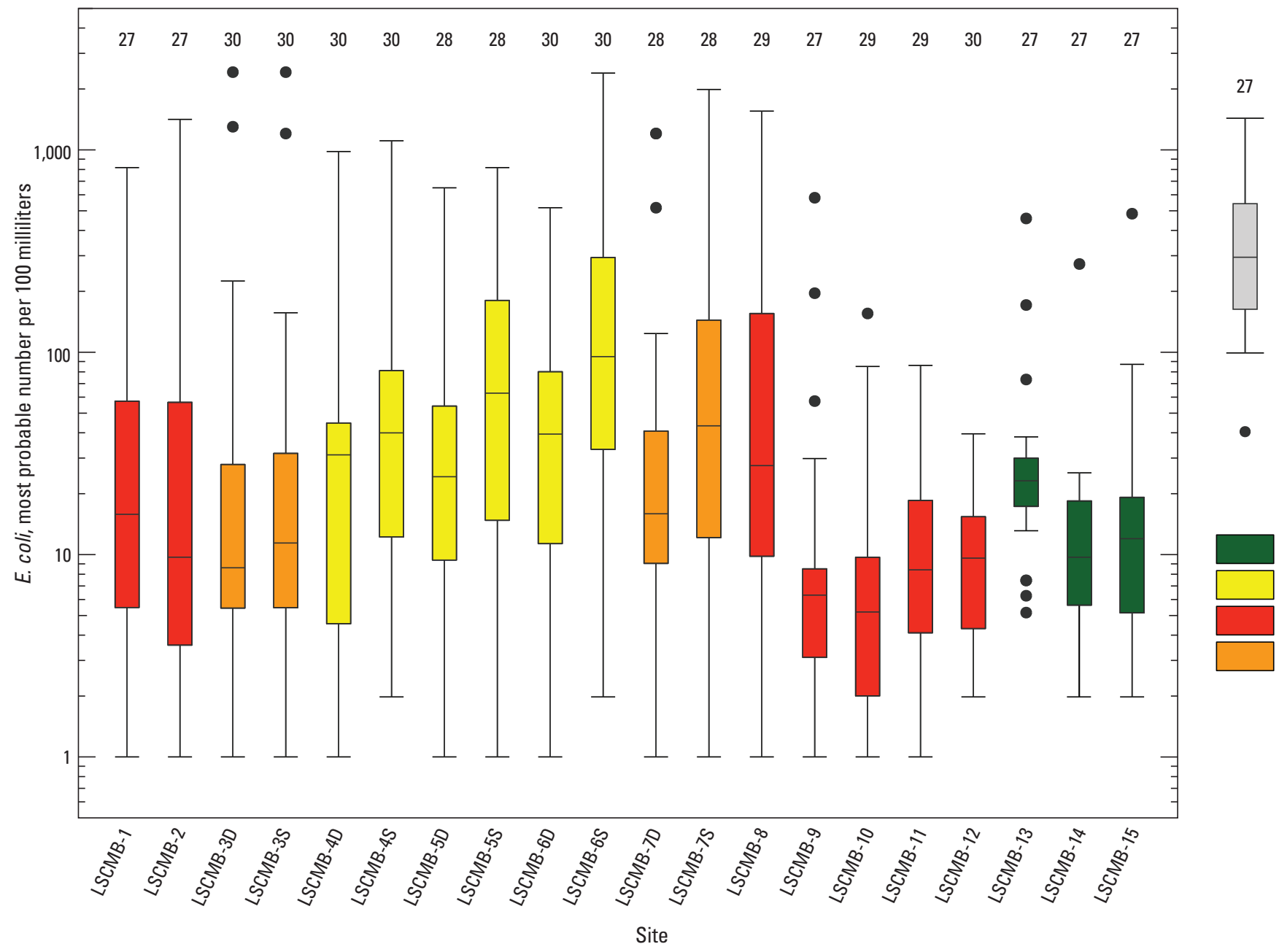

\section{EXPLANATION}

[Logarithmic scale]

Number of values

Largest value within 1.5 times

interquartile range above

75th percentile

75th percentile

50th percentile

(median)
25th percentile

Interquartile range

Sthe

ingest value within 1.5 times

interquartile range below

25th percentile

- $\quad$ Outside value-Value is $>1.5$

times and $<3$ times the interquartile

range beyond either end of the box

Sampling sites

Black Creek (BC)

Designated swimming area (DSA)

Park shoreline (PS)

Recreational area near beach (RNB)

Figure 4. Boxplots of Escherichia coli (E. coli) concentrations in $\log _{10}$ scale in shallow and deep nearshore surface water.-Continued 
Table 8. Summary of exceedances of Escherichia coli concentrations compared the State of Michigan Recreational Water-Quality Criterion for total body contact for a single event at Lake St. Clair Metropark Beach based on sampling location, 2018-2019.

[MPN, most probable number; $\mathrm{mL}$, milliliter]

\begin{tabular}{lccc}
\hline \multicolumn{1}{c}{ Sample location } & Number of samples & $\begin{array}{c}\text { Number of samples } \\
\text { greater than } \mathbf{3 0 0} \\
\text { MPN/100 } \mathbf{~ m L}^{\mathbf{1}}\end{array}$ & Percent exceedance \\
\hline Park shoreline (PS) & 338 & 18 & 5.3 \\
Recreational area near beach (RNB)-Shallow & 98 & 15 & 15 \\
Recreational area near beach (RNB)-Deep & 98 & 8 & 8.2 \\
Designated swimming area (DSA)-Shallow & 148 & 31 & 21 \\
Designated swimming area (DSA)-Deep & 148 & 13 & 8.8 \\
Black Creek (BC) & 141 & 2 & 1.4 \\
Total & $\mathbf{9 7 1}$ & $\mathbf{8 7}$ & $\mathbf{9 . 0}$ \\
\hline
\end{tabular}

${ }^{1}$ The State of Michigan Recreational Water-Quality Criterion for total body contact for a single event is 300 colony forming units/100 milliliter (or 300 most probable number/100 milliliter) and is based on a geometric mean of three samples (Michigan Department of Environmental Quality, 2006).

To better understand if water coming in from Lake St. Clair was a source of higher beach $E$. coli concentrations or if high $E$. coli concentrations were a result of sources coming from land or nearshore locations, shallow and deep samples were compared from RNB and DSA sites (fig. 5). For most sample pairs, the shallow water sample had a higher E. coli concentration than the corresponding deep water sample, indicating concentrations are likely diluted in offshore Lake St. Clair waters with a source of E. coli coming from land or nearshore. There were 42 instances where the shallow concentration exceeded $300 \mathrm{MPN} / 100 \mathrm{~mL}$ and were greater than the deep sample. However, there were instances when deep water concentrations were similar or higher than the shallow water samples (below black line on fig. 5). There were only four instances in which the deep sample was greater than $300 \mathrm{MPN} / 100 \mathrm{~mL}$ and equal to or slightly greater than the shallow sample concentration. Of most significance, were those samples in which one or both samples were at or near the $300 \mathrm{MPN} / 100 \mathrm{~mL}$ threshold.

Evaluating results over time and comparing site locations also indicated the DSA-shallow and RNB-shallow samples were frequently greater than the PS, DSA-deep, RNB-deep, and $\mathrm{BC}$ samples (fig. 6) indicating a source from land or near the shoreline rather than offshore waters; however, there were sampling dates in which one or more sites had concentrations greater than or equal to samples from the shallow DSA/RNB sites. In most cases, the source seems to be from land and, in most cases, localized to a specific area. There were a total of five dates when $E$. coli concentrations, other than DSA shallow water samples, were greater than $300 \mathrm{MPN} / 100 \mathrm{~mL}$ from 2018-2019. The dates were as follows:
- On August 8, 22, and 29, 2018, and May 23, June 18, and July 9, 2019, one or two sites exceeded the $300 \mathrm{MPN} / 100 \mathrm{~mL}$ but all other sites had much lower E. coli concentrations. Because of the site-specific nature of the high concentrations, the presumed source was likely local to the sampling point and not indicative of a larger source of $E$. coli to the beach or surrounding waters.

- On September 21, 2018, concentrations were high at LSCMB sites 1-9. Shallow samples were greater than deep water samples, with highest concentrations at DSA shallow sites, although LSCMB-9 had equally high concentrations as the shallow sites. The areas received more than $0.5 \mathrm{in}$. of rain in the preceding 24 hours. The wind was primarily from the southsouthwest, southwest, and west-southwest from 14 to 26 miles per hour (mph; NOAA, 2020). Stormwater runoff from the shore and winds keeping water nearshore may be the source of high E. coli on this date, given increased relative concentrations in shallower waters (see "Stormwater" section).

- On May 9 and 28, 2019, E. coli concentrations exceeded $300 \mathrm{MPN} / 100 \mathrm{~mL}$ at sites LSCMB-1 and LSCMB-2 (east PS). On May 9, all sites from LSCMB 1-9 exceeded $300 \mathrm{MPN} / 100 \mathrm{~mL}$ except the deep samples at LSCMB sites 6 and 7. LSCMB-6D, LSCMB-7D, and LSCMB-9-15 sites were all less than $100 \mathrm{MPN} / 100 \mathrm{~mL}$. On May 9, no precipitation fell in 24 hours, wind speed was 9-20 $\mathrm{mph}$ (from 8 a.m.-2 p.m.) from the southeast, south-southeast, 


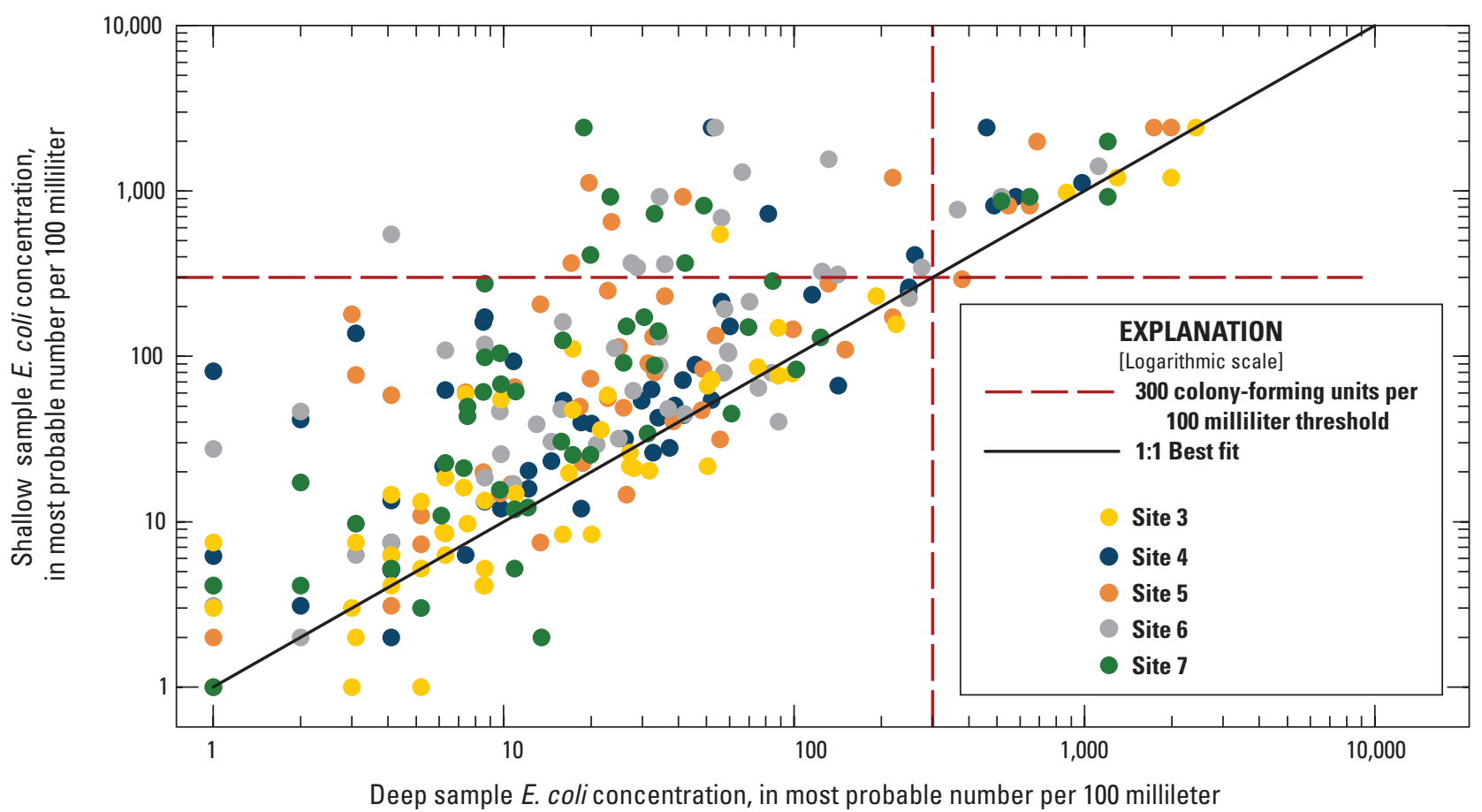

Figure 5. Escherichia coli (E. coli) concentrations in shallow and deep samples for the recreational area near beach and designated swimming area sampling sites at Lake St. Clair Metropark Beach in 2018-2019, logarithmic scale.

and south (NOAA, 2020). On May 28, only LSCMB-1 and LSCMB-2 sites exceeded the $300 \mathrm{MPN} / 100 \mathrm{~mL}$ E. coli threshold. On May 28, precipitation of 0.16 in. a 24-hour period was recorded with wind speed of 6-16 mph from the southwest, west-southwest, and west (NOAA, 2020). Because the wind was from the south on these dates, it is possible that a source near the east end of the park was contributing to high E. coli.

- On June 13, 2019, concentrations at the DSA and BC exceeded $300 \mathrm{MPN} / 100 \mathrm{~mL}$. Shallow samples were greater than deep samples for LSCMB sites 4-6 but the deep sample was greater than the shallow at LSCMB-7. On this date, BC samples also were greater than $300 \mathrm{MPN} / 100 \mathrm{~mL}$, but all other offshore samples were less than $300 \mathrm{MPN} / 100 \mathrm{~mL}$. The area received about $0.8 \mathrm{in}$. of rain within 24 hours preceding sample collection (NOAA, 2020). There are several storm drains are along BC. Stormwater from the park vicinity is a potential source of E. coli on this date (see "Stormwater" section).
- On July 11,2019 , and July 16,2019 , concentrations were greater than $300 \mathrm{MPN} / 100 \mathrm{~mL}$ at sites LSCMB 6-8. E. coli in shallow samples was greater than in deeper samples, and all other PS samples were $<100 \mathrm{MPN} / 100 \mathrm{~mL}$. Similar to other results, this indicates sources closer to land.

\section{Offshore Surface Water}

Samples were collected on August 7, and 14, 2019, about $3 \mathrm{ft}$ below the surface, along a transect north to the Clinton River to more thoroughly investigate Lake St. Clair offshore waters as a source of $E$. coli. The Clinton River was at base-flow condition on August 7, and the daily mean discharge at the USGS streamgage at Moravian Drive at Mt. Clemens, Mich. (USGS streamgage 04165500) on that date was $176 \mathrm{ft}^{3} / \mathrm{s}$ (fig. 7; U.S. Geological Survey 2020). On August 13, 2019, a rain event in the area produced 1.8 in. of rain (NOAA, 2020). During this rain event, the Clinton River flow peaked on August 13 and was starting to recede on August 14 . The daily mean discharge at USGS 04165500 on August 14 was $838 \mathrm{ft} 3 / \mathrm{s}$. Samples were collected on August 14 

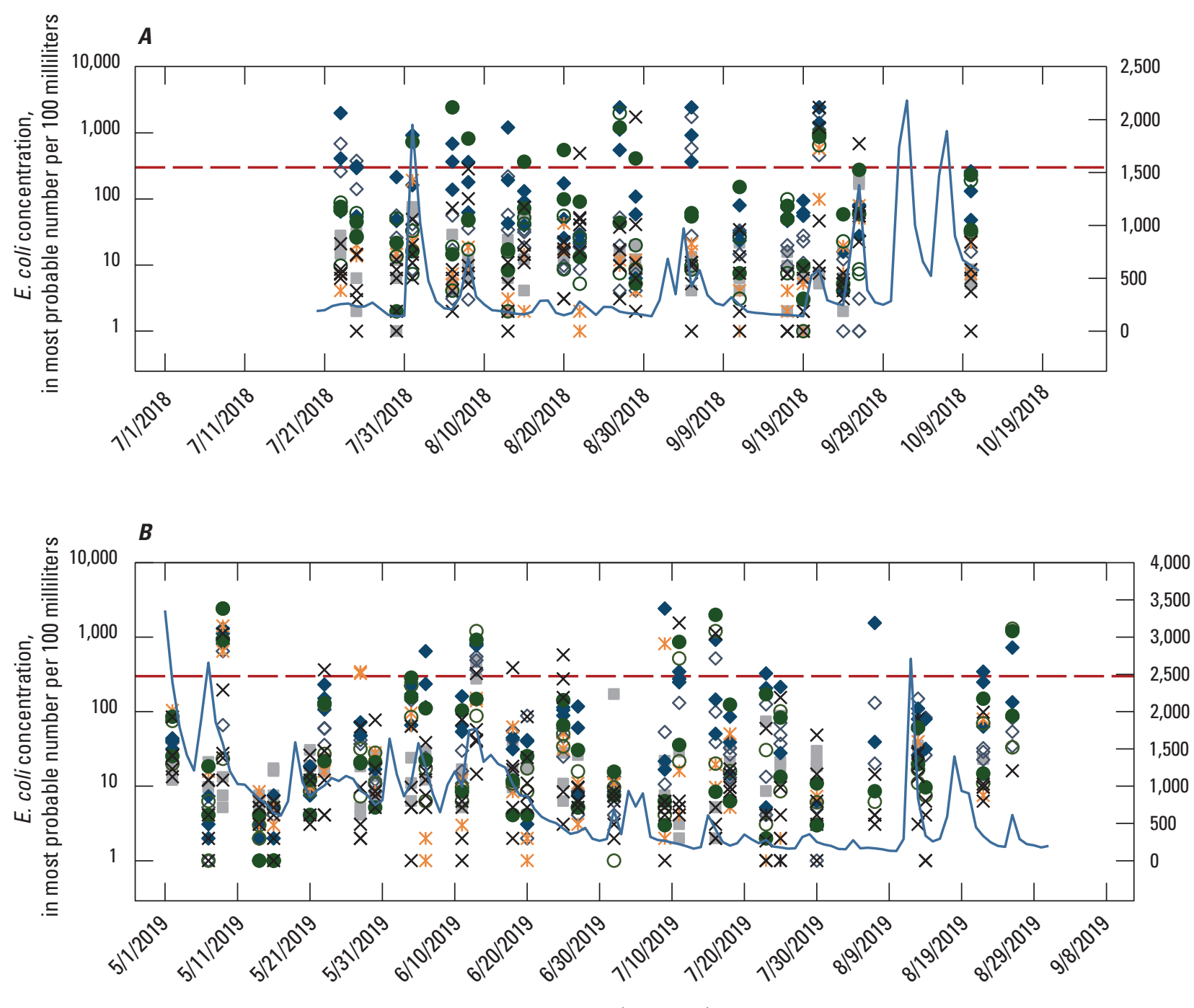

Date (m/d/yyyy)

\section{EXPLANATION}

[Logarithmic scale]

Daily discharge

— 300 most probable number (of bacteria) per 100 milliliter threshold

$\diamond \quad$ Designated swimming area-deep

* East park shoreline

- Recreational area near beach-shallow

Black Creek

- Designated swimming area-shallow

○ Recreational area near beach-deep

$\times \quad$ West park shoreline

Figure 6. Escherichia coli (E. coli) concentrations and daily discharge at USGS station 04165500 (U.S. Geological Survey, 2020) by date in, A, 2018 and, B, 2019 for the Lake St. Clair Metropark study, for sampling sites at Black Creek, east and west park shorelines, and shallow and deep samples for the recreational area near beach and the designated swimming area, logarithmic scale. 


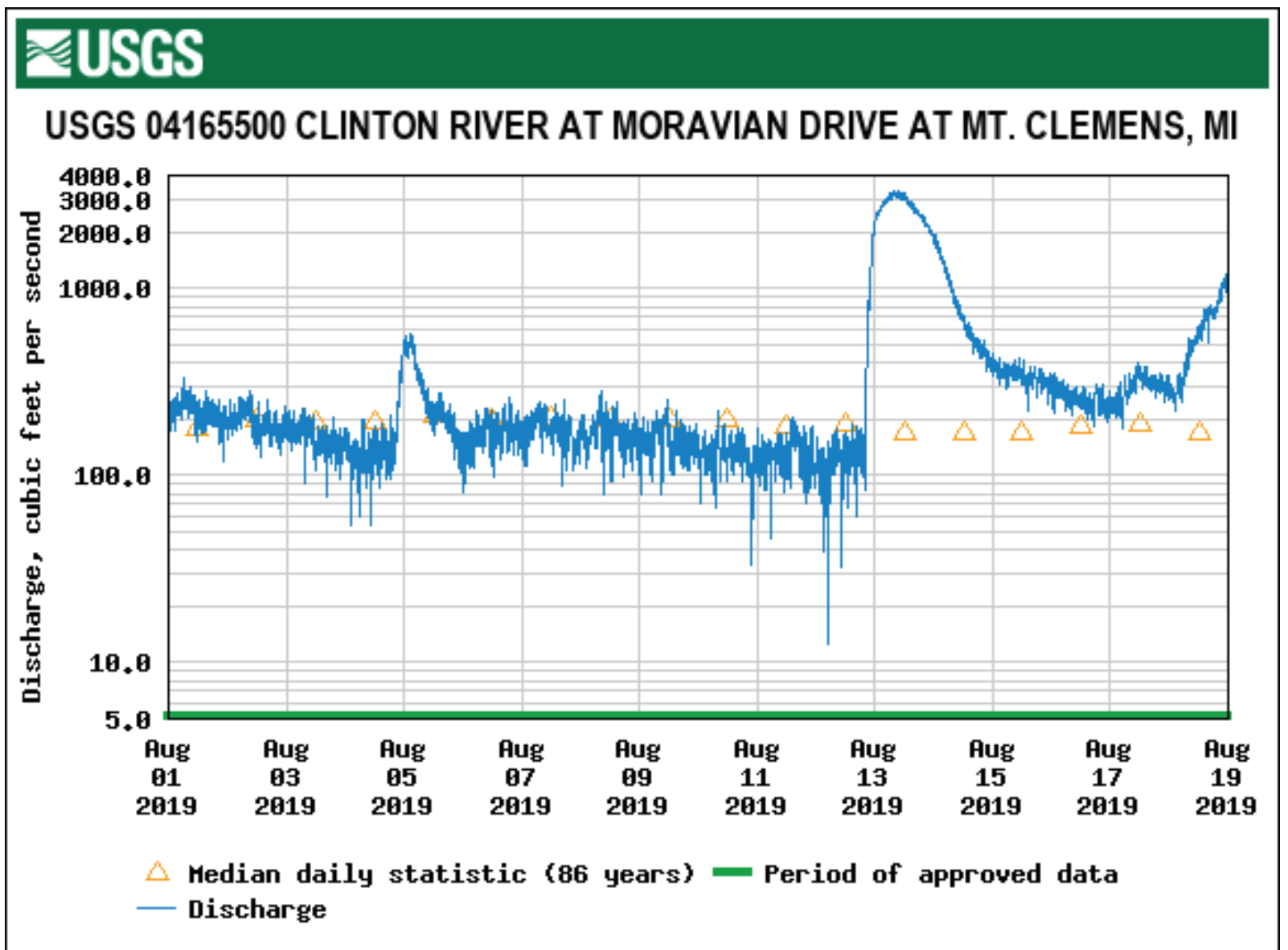

Figure 7. Daily mean discharge graph at the USGS streamgage 04165500 on the Clinton River at Moravian Drive at Mount Clemens, Michigan, August 1-19, 2019 (U.S. Geological Survey, 2020).

to capture stormwater contributions from the Clinton River to Lake St. Clair. Offshore E. coli concentrations ranged from $<1 \mathrm{MPN} / 100 \mathrm{~mL}$ to $11 \mathrm{MPN} / 100 \mathrm{~mL}$. MCHD measured E. coli concentrations in the Clinton River drainage basin on August 13 with results as high as $>24,000 \mathrm{MPN} / 100 \mathrm{~mL}$ (MCHD, 2020b). At the downstream-most site, the reported concentration was $41 \mathrm{MPN} / 100 \mathrm{~mL}$ at the mouth of the Clinton River to Lake St. Clair (MCHD site 41). At the next Clinton River site upstream (MCHD site 83), E. coli concentrations were orders of magnitude higher: 9,800 MPN/100 mL (MCHD, 2020b), coinciding with peak flow of the Clinton River (fig. 7). Once the Clinton River discharges into Lake St. Clair, E. coli are diluted and does not affect LSCMB. These data also support the hypothesis of a localized source of $E$. coli near the beach rather than the Clinton River. Given the high concentrations observed in the Clinton River drainage basin after rain, overland flow may be a source of $E$. coli in this landscape.

\section{Stormwater}

To determine the effect stormwater might have on beach concentrations of $E$. coli, samples were collected from several sites: $\mathrm{BC}$ storm drain outlets, standing water on the beach, and standing water on grass near the beach area. It was observed in the field that during heavy rain events, the pooling water washed out beach sand into the shallow water (figs. 8 and 9). Water samples were collected from directly in front of these washouts and from standing water on the beach or grass to represent what effect runoff could have on the DSA. Twenty samples (LSCMB-D1, D2, D3) were collected at storm drain outlets along BC (fig. 2). Storm drain outlets were 3-7 feet below the water surface in $\mathrm{BC}$. Concentrations measured at storm drain outlets were generally less than $300 \mathrm{MPN} / 100 \mathrm{~mL}$ (table 9). The 2 samples that exceeded $300 \mathrm{MPN} / 100 \mathrm{~mL}$ were collected on June 13, 2019. Because the storm drain outlet is under water along the shoreline of $\mathrm{BC}$, it is difficult to 
determine the actual concentration of $E$. coli from the stormwater versus BC. Similarly, high concentrations were also seen in the $\mathrm{BC}$ samples (fig.6), and were also in exceedance of $300 \mathrm{MPN} / 100 \mathrm{~mL}$. More notable are the $E$. coli concentrations detected in standing water at the beach or on the grass areas near the beach (table 10). In most cases, the concentrations exceeded the maximum quantification concentration of 2,419 MPN/100 mL.

\section{Sediment, Sand, Detritus}

Accumulation of detritus was frequently observed along the shore. Eleven detritus samples were collected over three sampling dates (table 4). Out of the 11 samples, 10 had E. coli concentrations greater than $300 \mathrm{MPN} / \mathrm{g} \mathrm{dw}$. The median concentration observed was $6,300 \mathrm{MPN} / \mathrm{g} \mathrm{dw}$ with a maximum concentration of greater than 42,000 MPN/g dw (table 11). To compare sediment across sampling years, a reporting level of $14 \mathrm{MPN} / \mathrm{g} \mathrm{dw}$ was used for all samples. If $E$. coli was not detected or if concentration were detected below $14 \mathrm{MPN} / \mathrm{g} \mathrm{dw}$, values were reported as below reporting level (BRL).

In 2018, beach sand and lake-bottom sediment samples were collected to assess $E$. coli concentration on sediments at LSCMB. A total of 26 lake-bottom sediment samples were collected offshore in DSA and RNB areas (table 3 and 11), 13 samples were BRL (table 11). The median $E$. coli concentration for lake-bottom E. coli was $17 \mathrm{MPN} / \mathrm{g}$ dw with a maximum of $910 \mathrm{MPN} / \mathrm{g} \mathrm{dw}$. Two out of the 26 samples (8 percent) were great than $300 \mathrm{MPN} / \mathrm{g} \mathrm{dw}$ and were collected nearshore in shallow water less than 3 - $\mathrm{ft}$ deep in the DSA (USGS sites 423414082474204 and 423415082474604 ). Higher concentrations were detected in the surface beach sand associated with DSA (table 11). Although the median

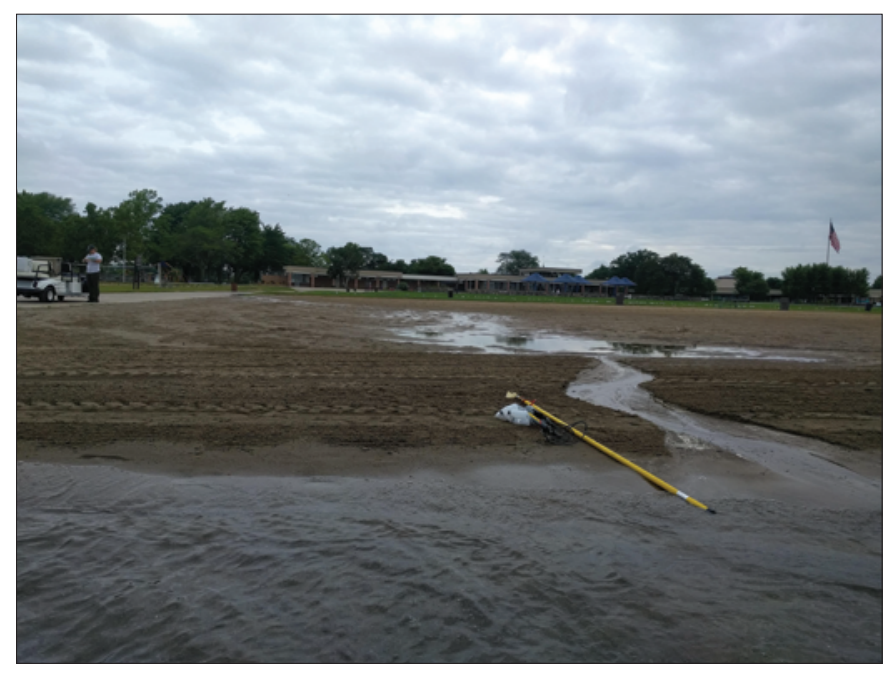

Figure 8. Photograph of Lake St. Clair Metropolitan Beach from offshore showing standing water on beach draining into Lake St. Clair after a storm event on May 9, 2019. Photograph by Jessica Maurer, U.S. Geological Survey. concentration for all 2018 beach sand samples was BRL, the percentage of samples greater than $300 \mathrm{MPN} / \mathrm{g} \mathrm{dw}$ was 12 percent, with $11,000 \mathrm{MPN} / \mathrm{g}$ dw the highest concentration observed. Separating the samples by depth, E. coli was greater than $300 \mathrm{MPN} / \mathrm{g}$ dw in 34 percent of the 29 surface samples, and 0 percent of the 53 samples collected at $1-3-\mathrm{ft}$ depths (table 11).

In 2019, a total of 88 beach sand samples were collected on the beach in the DSA along transects from the lake and upland on the beach. Concentrations greater than 29,000 MPN/g dw were detected and 22 percent $(\mathrm{n}=19)$ exceeded $300 \mathrm{MPN} / \mathrm{g}$ dw (table 11). Concentrations were highest in the surface sand and decreased with depth (table 11). Samples were also highest $(>42,000)$ in samples collected near the lake interface and decrease upland (table 12). Field observations note that despite best efforts to only collect beach sand, samples on some occasion may contain some detritus as well as the detritus tend to build up in the areas where water washes to the shore.

To determine if precipitation events increased E. coli concentrations at the beach, samples were collected during dry periods and after rain. For the purpose of this report in comparing "dry" and "wet" conditions, we used the rainfall variables determined in a previous study (Francy and others, 2006). In the paper, "dry" conditions are when rainfall equals $0 \mathrm{in}$. and "wet" conditions are when rainfall is greater than $0.10 \mathrm{in}$. within the 24-hour period preceding the day of sampling (9 a.m. to 9 a.m.). In 2018 all samples were collected under dry conditions. In 2019, beach sand was collected four times: June 13, 2019, and August 13, 2019, under wet conditions, and July 23, 2019, and August 26, 2019, under dry conditions. Results are reported in table 13. E. coli concentrations were similar and varied by date more so than wet or dry.

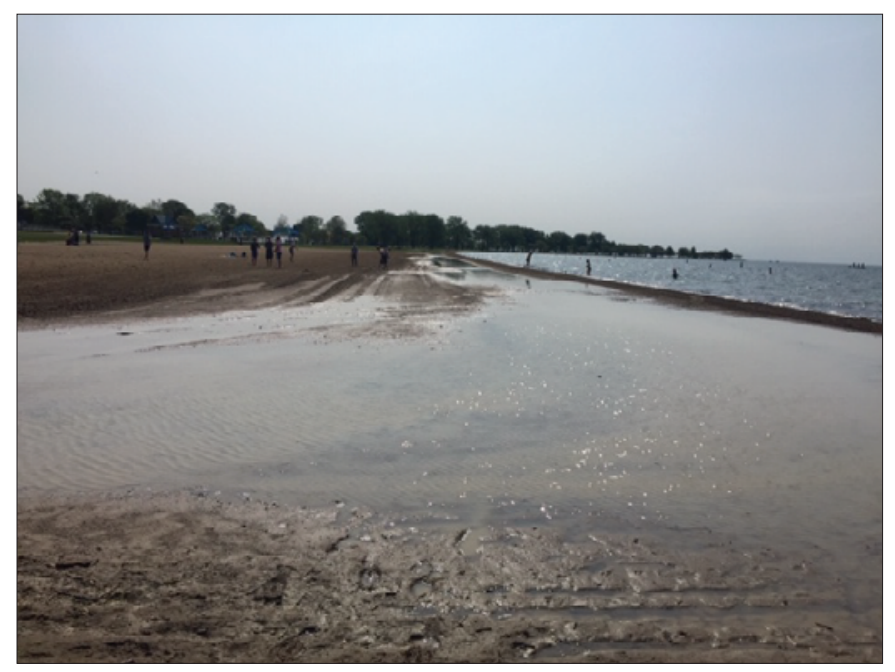

Figure 9. Photograph of Lake St. Clair Metropolitan Beach from onshore showing standing water on beach draining into Lake St. Clair after a storm event on August 1, 2018. Photograph by Jessica Maurer, U.S. Geological Survey. 
Table 9. Descriptions of storm drain outlet samples collected along Black Creek and Escherichia coli concentrations for the Lake St. Clair Metropolitan Beach study in 2018 and 2019.

[ID, identification; USGS, U.S. Geological Survey; MPN, most probable number; mL, milliliter; LSCMB, Lake St. Clair Metropark Beach; N/A, not available]

\begin{tabular}{|c|c|c|c|c|c|c|c|}
\hline Site ID & USGS station ID & $\begin{array}{l}\text { Sample time } \\
\text { frame }\end{array}$ & $\begin{array}{l}\text { Number } \\
\text { of samples }\end{array}$ & $\begin{array}{c}\text { Minimum } \\
\text { MPN/100 mL }\end{array}$ & $\begin{array}{c}\text { Median } \\
\text { MPN/100 mL }\end{array}$ & $\begin{array}{c}\text { Maximum } \\
\text { MPN/100 mL }\end{array}$ & $\begin{array}{c}\text { Number of samples } \\
\text { greater than } 300 \\
\text { MPN/100 mL }\end{array}$ \\
\hline \multirow{2}{*}{ LSCMB-D1 } & \multirow{2}{*}{423412082471603} & July-Oct 2018 & $\mathrm{~N} / \mathrm{A}$ & $\mathrm{N} / \mathrm{A}$ & $\mathrm{N} / \mathrm{A}$ & N/A & N/A \\
\hline & & May-Sep 2019 & 2 & 12 & 14 & 16 & 0 \\
\hline \multirow{2}{*}{ LSCMB-D2 } & \multirow{2}{*}{423415082471903} & July-Oct 2018 & 6 & 4.0 & 12 & 88 & 0 \\
\hline & & May-Sep 2019 & 4 & 6.0 & 22 & 370 & 1 \\
\hline LSCMB-D3 & 423425082473203 & May-Sep 2019 & 4 & 10 & 16 & 330 & 1 \\
\hline
\end{tabular}

Table 10. Descriptions of standing water samples collected and Escherichia coli concentrations for the Lake St. Clair Metropolitan Beach Study in 2018 and 2019.

[USGS, U.S. Geological Survey; ID, identification; MPN, most probable number; mL, milliliter; >, greater than]

\begin{tabular}{ccccccc}
\hline $\begin{array}{c}\text { Storm sample } \\
\text { type }\end{array}$ & USGS station ID & $\begin{array}{c}\text { Number of } \\
\text { samples }\end{array}$ & $\begin{array}{c}\text { Minimum } \\
\text { MPN/100 mL }\end{array}$ & $\begin{array}{c}\text { Median } \\
\text { MPN/100 } \mathbf{~ m L}\end{array}$ & $\begin{array}{c}\text { Maximum } \\
\text { MPN/100 } \mathbf{~ m L}\end{array}$ & $\begin{array}{c}\text { Number of samples } \\
\text { greater than } \mathbf{3 0 0} \\
\text { MPN/100 } \mathbf{~ m L}\end{array}$ \\
\hline & 423418082474101 & 4 & 440 & $>2,400$ & $>2,400$ & 4 \\
Standing water & 423418082474202 & 3 & 260 & $>2,400$ & $>2,400$ & 2 \\
on grass & 423415082473601 & 1 & 200 & 200 & 200 & 0 \\
& 423415082473802 & 1 & $>2,400$ & $>, 2400$ & $>2,400$ & 1 \\
& Total of all samples & $\mathbf{9}$ & $\mathbf{2 0 4}$ & $>\mathbf{2 , 4 0 0}$ & $>\mathbf{2 , 4 0 0}$ & $\mathbf{7}$ \\
\hline \multirow{3}{*}{$\begin{array}{c}\text { Standing water } \\
\text { on beach }\end{array}$} & 423417082475003 & 5 & $>2,400$ & $>2,400$ & $>2,400$ & 5 \\
& 423416082474301 & 3 & $>2,400$ & $>2,400$ & $>2,400$ & 3 \\
& 423416082474201 & 8 & $>2,400$ & $>2,400$ & $>2,400$ & 8 \\
& 423416082474201 & 1 & $>2,400$ & $>2,400$ & $>2,400$ & 1 \\
\hline
\end{tabular}

Early and late in the season, there were lower E. coli concentrations, and during mid-summer, there were higher E. coli concentrations. This is consistent with other beach studies (Whitman and Nevers, 2008; Chen and Chang, 2014; Ishii and others, 2007). It is difficult to compare between the wet and dry samplings or between sampling years - the first year of the study started later in the recreational season, so the number of sampling trips was limited by sparse rain events, field personnel availability, and cost of analysis.

\section{Groundwater}

Surface-water monitoring indicated the source of high E. coli concentrations at LSCMB was most likely coming from land or near the shore rather than from the offshore waters of Lake St. Clair. To help beach managers identify possible localized sources, further investigations were done onshore. Water samples were collected from the shallow groundwater at the swimming beach area (fig. 10) on two occasions in 2018 and three in 2019 (table 2). Shallow groundwater was less than 1-ft deep at the land-water interphase and 2- to 3-ft deep upland. On most dates, samples were collected along two to three transects along the beach (east, central, west). Samples were collected from water's edge (A) and upland B and C (fig. 10). In 2018, groundwater samples were not diluted and most exceeded the Colilert-18 detection limits of 2,419 MPN/100 mL for undiluted samples. In 2019, samples were diluted for quantification. Out of 44 groundwater samples analyzed, 34 had $E$. coli concentrations greater than $300 \mathrm{MPN} / 100 \mathrm{~mL}$ (table 14). In general, samples collected from groundwater near the lake had the highest $E$. coli 
Table 11. Summary statistics of Escherichia coli concentrations in detritus and beach sand samples collected at the surface and at depth for the Lake St. Clair Metropolitan Beach study in 2018 and 2019.

[MPN, most probable number; g dw, grams dry weight; BRL, below reporting level of $14 \mathrm{MPN} / \mathrm{g} \mathrm{dw}$; >, greater than; ft, foot]

\begin{tabular}{|c|c|c|c|c|c|c|}
\hline Depth & $\begin{array}{c}\text { Number of } \\
\text { samples }\end{array}$ & $\begin{array}{l}\text { Minimum } \\
\text { MPN/g dw }\end{array}$ & $\begin{array}{l}\text { Median } \\
\text { MPN/g dw }\end{array}$ & $\begin{array}{l}\text { Maximum } \\
\text { MPN/g dw }\end{array}$ & $\begin{array}{c}\text { Number of } \\
\text { samples } \\
\text { greater than } \\
300 \mathrm{MPN} / \mathrm{g} \mathrm{dw}\end{array}$ & $\begin{array}{c}\text { Percent } \\
\text { exceeding } \\
300 \mathrm{MPN} / \mathrm{g} \mathrm{dw}\end{array}$ \\
\hline Detritus & 11 & 72 & 6300 & $>42,000$ & 10 & 91 \\
\hline Lake-bottom sediment & 26 & BRL & 17 & 910 & 2 & 8 \\
\hline \multicolumn{7}{|l|}{2018 beach sand } \\
\hline Surface (0 ft depth) & 29 & BRL & 76 & 11,000 & 10 & 34 \\
\hline $\operatorname{Mid}(1 \mathrm{ft}$ depth$)$ & 24 & BRL & BRL & 36 & 0 & 0.0 \\
\hline Bottom (2-3 ft depth) & 29 & BRL & BRL & BRL & 0 & 0.0 \\
\hline 2018 Total & 82 & BRL & BRL & 11,000 & 10 & 12 \\
\hline \multicolumn{7}{|l|}{2019 beach sand } \\
\hline Surface (0 ft depth) & 33 & BRL & 450 & $>29,000$ & 18 & 55 \\
\hline $\operatorname{Mid}(1-1.5 \mathrm{ft}$ depth $)$ & 33 & BRL & BRL & 691 & 1 & 3 \\
\hline Bottom (2-3 ft depth) & 22 & BRL & BRL & 28 & 0 & 0 \\
\hline 2019 Total & 88 & BRL & 17 & $>29,000$ & 19 & 22 \\
\hline
\end{tabular}

Table 12. Summary statistics of Escherichia coli concentrations in beach sand samples collected along transects at the beach for Lake St. Clair Metropolitan Beach study in 2018 and 2019.

[MPN, most probable number; g dw, grams dry weight; BRL, below reporting level of $14 \mathrm{MPN} / \mathrm{g} \mathrm{dw}$; >, greater than]

\begin{tabular}{|c|c|c|c|c|c|c|}
\hline Sample by location from shore & $\begin{array}{l}\text { Number of } \\
\text { samples }\end{array}$ & $\begin{array}{l}\text { Minimum } \\
\text { MPN/g dw }\end{array}$ & $\begin{array}{c}\text { Median } \\
\text { MPN/g dw }\end{array}$ & $\begin{array}{l}\text { Maximum } \\
\text { MPN/g dw }\end{array}$ & $\begin{array}{c}\text { Number of samples } \\
\text { greater than } \\
300 \text { MPN/g dw }\end{array}$ & $\begin{array}{c}\text { Percent } \\
\text { exceeding } \\
300 \mathrm{MPN} / \mathrm{g} \text { dw }\end{array}$ \\
\hline "A" samples nearest lake & 33 & BRL & 560 & $>42,000$ & 15 & 45 \\
\hline "B" samples midway up beach & 33 & BRL & BRL & $>29,000$ & 8 & 24 \\
\hline "C" samples farthest upland on beach & 33 & BRL & BRL & 3,500 & 5 & 15 \\
\hline
\end{tabular}

Table 13. Summary statistics of Escherichia coli concentrations in beach sand samples collected during wet and dry conditions for Lake St. Clair Metropolitan Beach study in 2018 and 2019.

[MPN, most probable number; g dw, grams dry weight; BRL, below reporting level of $14 \mathrm{MPN} / \mathrm{g} \mathrm{dw}$; >, greater than]

\begin{tabular}{|c|c|c|c|c|c|c|}
\hline Sampling date & $\begin{array}{l}\text { Number of } \\
\text { samples }\end{array}$ & $\begin{array}{l}\text { Minimum } \\
\text { MPN/g dw }\end{array}$ & $\begin{array}{c}\text { Median } \\
\text { MPN/g dw }\end{array}$ & $\begin{array}{l}\text { Maximum } \\
\text { MPN/g dw }\end{array}$ & $\begin{array}{c}\text { Number of } \\
\text { samples } \\
\text { greater than } \\
300 \mathrm{MPN} / \mathrm{g} \mathrm{dw}\end{array}$ & $\begin{array}{c}\text { Percent } \\
\text { exceeding } \\
300 \mathrm{MPN} / \mathrm{g} \text { dw }\end{array}$ \\
\hline All 2018 (dry) & 82 & BRL & BRL & 11,000 & 10 & 12 \\
\hline 6/13/2019 (wet) & 16 & BRL & 18 & 298 & 0 & 0.0 \\
\hline 7/23/2019 (dry) & 24 & BRL & 19 & 8,500 & 8 & 33 \\
\hline 8/26/2019 (dry) & 24 & BRL & BRL & 5,000 & 5 & 21 \\
\hline
\end{tabular}



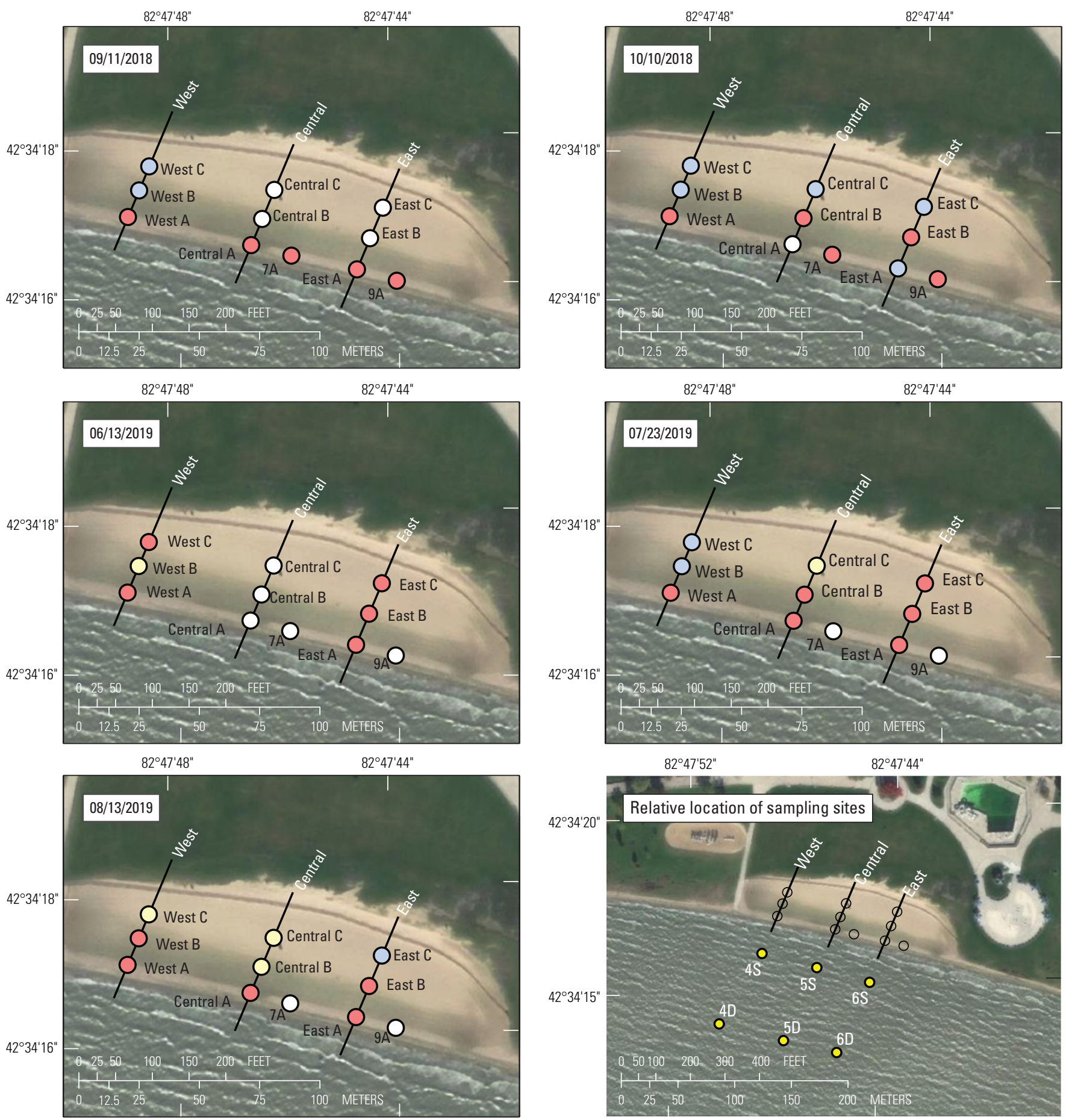

Map image is the intellectual property of Esri and is used herein under license Copyright ( 2014 Esri and its licensors. All rights reserved

\section{EXPLANATION}

[S=shallow; D=deep dates in mm/dd/yyyy]

\section{Groundwater transects}

E. coli concentration, most probable number per 100 milliliters
Not sampled
O 301 to 1000
$0<300$
$\mathrm{O}>1000$

Figure 10. Lake St. Clair Metropark Beach showing groundwater sampling sites and Escherichia coli (E. coli) concentrations on different dates in 2018-2019. 
Table 14. Summary of Escherichia coli concentrations in groundwater samples for each sample collection date for the Lake St. Clair Metropolitan Beach Study in 2018 and 2019.

[MPN, most probable number; $\mathrm{mL}$, milliliter; dates displayed in $\mathrm{m} / \mathrm{d} / \mathrm{yyyy}]$

\begin{tabular}{|c|c|c|c|c|c|c|c|}
\hline Condition & Date & $\begin{array}{l}\text { Number of } \\
\text { samples }\end{array}$ & $\begin{array}{l}\text { Minimum } \\
\text { MPN/100 mL }\end{array}$ & $\begin{array}{c}\text { Median } \\
\text { MPN/100 mL }\end{array}$ & $\begin{array}{l}\text { Maximum } \\
\text { MPN/100 mL }\end{array}$ & $\begin{array}{c}\text { Number of samples } \\
\text { greater than } \\
300 \text { MPN/100 mL }\end{array}$ & $\begin{array}{c}\text { Percent } \\
\text { exceedance }\end{array}$ \\
\hline Dry & $10 / 10 / 2018$ & 11 & 52 & 8200 & $>2,400$ & 6 & 63 \\
\hline Dry & $7 / 23 / 2019$ & 9 & 98 & 4,600 & 16,000 & 7 & 78 \\
\hline Wet & $9 / 11 / 2018$ & 9 & 150 & $>2,400$ & $>2,400$ & 7 & 78 \\
\hline
\end{tabular}

concentrations detected in this study; (fig. 10). Concentrations often decreased as sampling points moved upland but, in most cases, remained higher than $300 \mathrm{MPN} / 100 \mathrm{~mL}$ (fig. 10). The more upland the sample, the deeper the groundwater table. The decrease may be a result of increased sand barrier between the surface and groundwater. Alternatively, the groundwater sample locations closer to the lake may also be affected by lake water.

To determine if rain contributed to groundwater E. coli samples, results were grouped into "wet" and "dry" conditions based on rainfall similar to sediment samples. "Wet" conditions, determined by receiving rain in the preceding 24 hours, were sampled on September 11, 2018, June 13, 2019, and August 13, 2019. "Dry" conditions, determined by receiving no rain in the preceding 24 hours, were sampled on October 10, 2018, and July 23, 2019. E. coli in groundwater results varied on the different sampling dates with 33-100 percent exceedance of $300 \mathrm{MPN} / 100 \mathrm{~mL}$ overall. The two "dry" events had the lowest percent exceedance: 63 percent on October 10, 2018, and 78 percent on July 23, 2019 (table 14). But with only a few sample collection dates, it is difficult to determine the factors responsible for the difference in concentrations observed. Regardless, given the high concentrations detected in the groundwater, this could be a source of $E$. coli in swimming waters under specific conditions but was not assessed in this study.

\section{Environmental Factors}

The Pearson correlation coefficient was computed between many environmental variables and $E$. coli concentrations measured at LSCMB (table 15) to explore their potential relations. The coefficient produced from the Pearson analysis provides a measure of how closely related two variables are with positive one being a perfect and direct correlation and a negative one being a perfect and inverse correlation. Correlations close to zero are considered weak or not correlated. In this study, E. coli concentrations were not statistically correlated (values less than 0.35 ) with common environmental variables such as wind, precipitation, or waves. While standing water after a rain event contained high concentrations of E. coli, there was not a correlation between rainfall (wet/dry) conditions and E. coli concentration in the surface water or groundwater (fig. 11) nor for precipitation (table 15).

Table 15. Correlation coefficients for Escherichia coli concentrations in relation to selected environmental variables for Lake St. Clair Metropark Beach in 2018-2019.

\begin{tabular}{lc}
\hline \multicolumn{1}{c}{ Environmental variable } & Correlation coefficient \\
\hline Water temperature & 0.3555 \\
Clinton River temperature & 0.2944 \\
5-day cumulative precipitation & 0.2856 \\
Wave direction & 0.2418 \\
4-day cumulative precipitation & 0.2341 \\
3-day cumulative precipitation & 0.1935 \\
Clinton River turbidity & 0.1796 \\
Clinton River discharge & 0.1450 \\
pH & 0.1369 \\
Wave height & 0.1311 \\
Air temperature & 0.1267 \\
Clinton River velocity & 0.1093 \\
Wave periods & 0.1007 \\
Eastward air velocity & 0.1005 \\
2-day cumulative precipitation & 0.0797 \\
Lake St, Clair specific conductance & 0.0327 \\
Dewpoint & -0.0845 \\
Clinton River specific conductance & -0.1542 \\
Cloud cover & -0.1580 \\
Northward air velocity & -0.1799 \\
Clinton River dissolved oxygen & -0.2794 \\
\hline
\end{tabular}




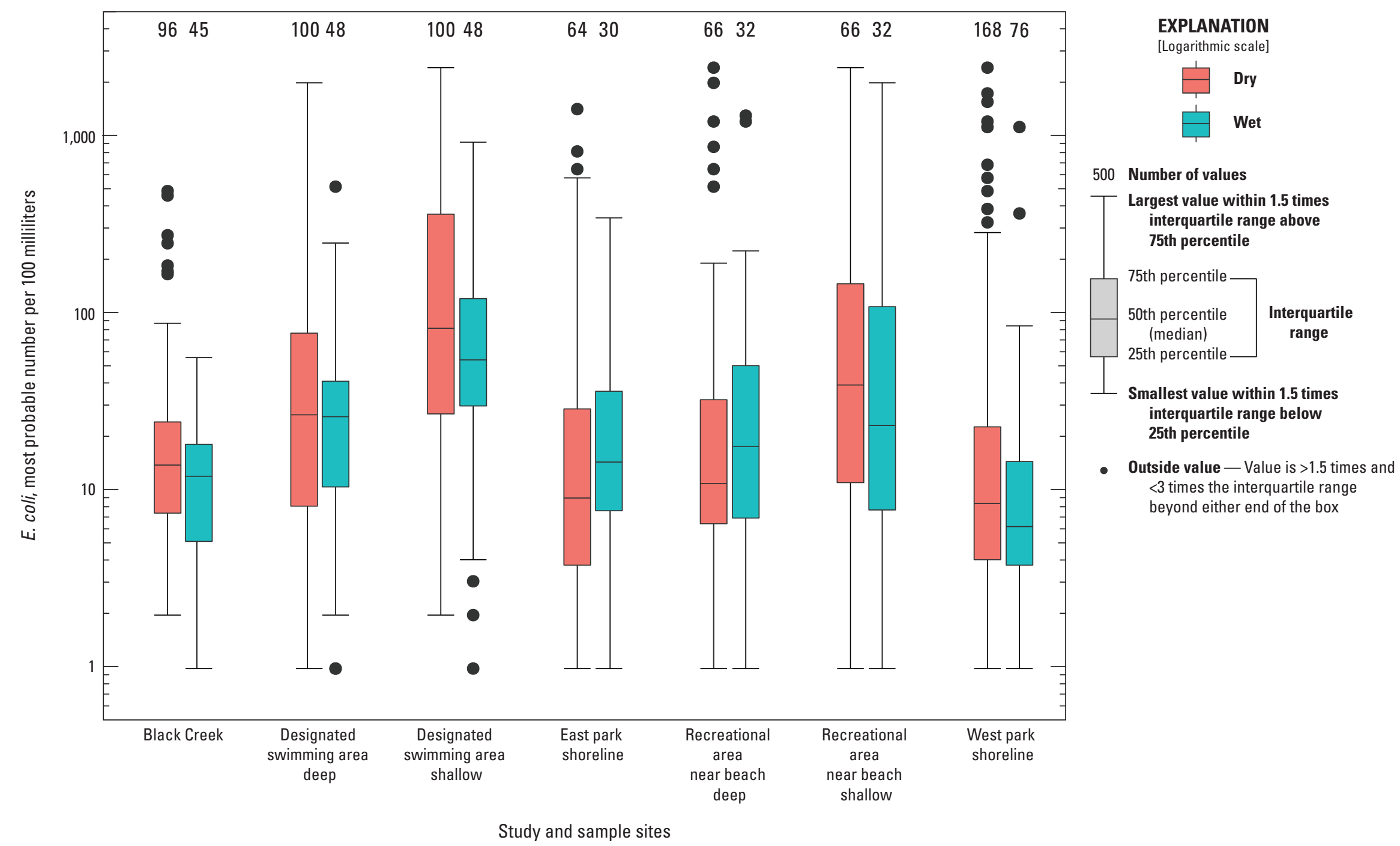

Figure 11. Escherichia coli (E. coli) concentrations for samples collected during wet and dry conditions at Lake St. Clair Metropark in $2018-2019$. 


\section{Microbial Source Tracking}

For the first year of the study, results indicated the source of $E$. coli was probably not coming from offshore Lake St. Clair waters but rather from localized sources at or near the beach. Waterfowl (in particular gulls) were suspected as a potential source of $E$. coli. Because of the number of beach visitors, a marker for human fecal contamination was also evaluated and might come from leaking wastewater or storm systems. A total of 146 samples were analyzed for human (HF183) markers and waterfowl (GFD) markers; 11 (8 percent) had a human marker detection and 22 (15 percent) had a waterfowl marker detection (table 16). The GFD marker was not detected in offshore surface-water samples nor BC water samples. A greater percentage of DSA and RNB shallow samples had detection of GFD (40 percent) than DSA and RNB deep samples (10 percent). On shore, GFD was detected in detritus and surface beach sand 50 percent and 19 percent of samples, respectively. GFD was detected in a lower percentage ( 7 percent) of beach sand at 1-ft depth and not detected in beach sand at 2-ft depth. Additionally, GFD was detected in 22 percent of the groundwater samples. Only one standing water sample was analyzed for MST markers which was positive for GFD. HF183 was not detected in surface water offshore, BC, PS, or shallow DSA or shallow RNB samples. It was not detected in the single standing water sample. HF183 was detected in 7-13 percent of groundwater and solid samples.

Despite a small percentage of detections, there was a relation between detection of the GFD marker and E. coli concentrations (fig. 12) in surface and groundwater. A Wilcoxon rank sum exact test was run to determine if there was a significant difference in E. coli concentrations when
MST markers were detected or not detected. At a 95-percent confidence (p-values less than 0.05) there was significant difference in $E$. coli concentrations for samples positive for GFD for surface-water and groundwater samples. There were only three HF183 detections, so no statistical analysis was done. Similarly, both MST markers were detected in low percentage in sand and detritus samples, and there was no statistically significant difference in $E$. coli concentrations in samples with detection compared to those without detections.

\section{Synopsis of Escherichia coli Results}

Continued progress is being made in reducing sources of fecal pollution in the Clinton River AOC, yet beach closures at LSCMB remain a concern. Monitoring by MCHD has determined high concentrations of $E$. coli in the Clinton River and contributing drainage basin. Discharging to the north of the LSCMB, the Clinton River has been identified as a possible source of contamination to the beach. Other environmental variables (such as wind speed and direction, precipitation, and water levels) have also been noted as environmental factors that correlate to high E. coli concentrations at the beach, and this indicates E. coli may come from offshore (Holtschlag and others, 2008); however, nearshore sources such as stormwater, waterfowl, and park visitors may also contribute to the $E$. coli concentrations. This study evaluated the E. coli concentrations nearshore and offshore of LSCMB to determine likely sources of $E$. coli in swimming waters that result in beach closures. Throughout the study, quality control samples were collected to determine the level of bias and variability. All field blanks were negative providing confidence that there was not a systemic contamination affecting sample results. Variability in

Table 16. Description of microbial source tracking results for human (HF183) and waterfowl (GFD) markers and Escherichia coli concentrations.

[BC, Black Creek; PS, park shoreline; DSA, designated swimming area; RNB, recreational area near beach; ft, feet]

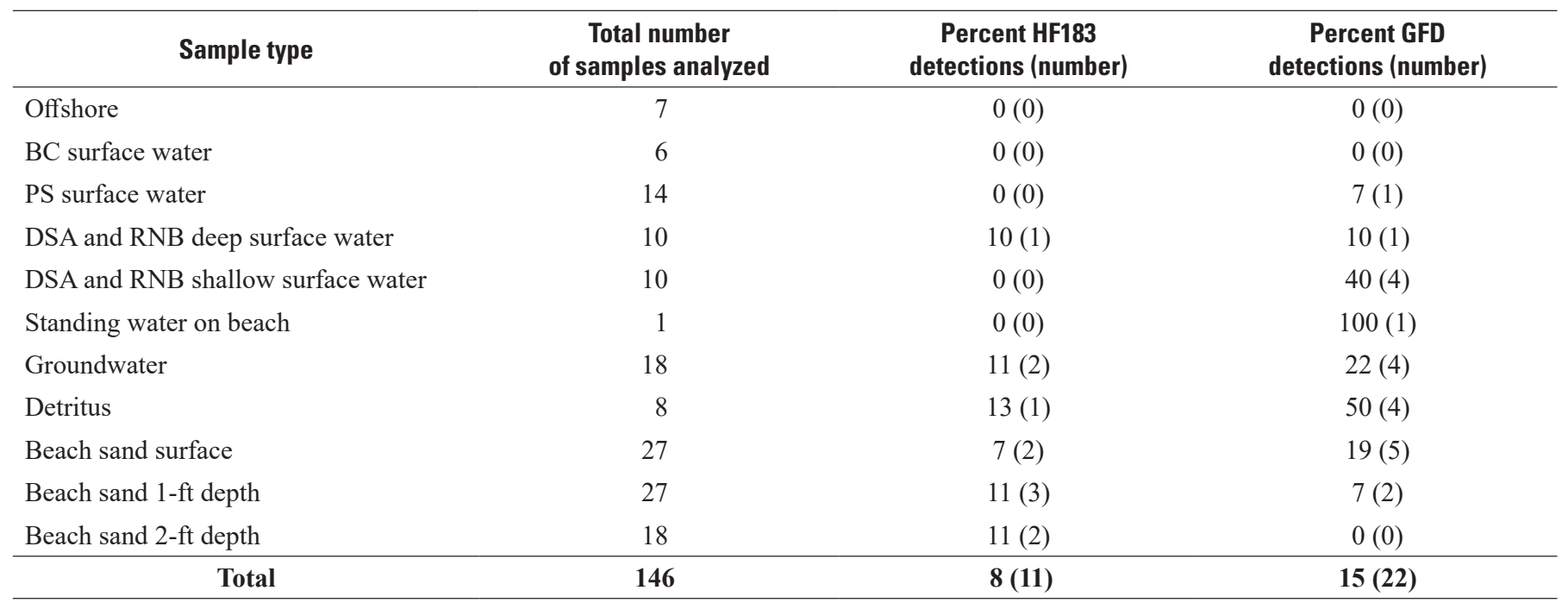



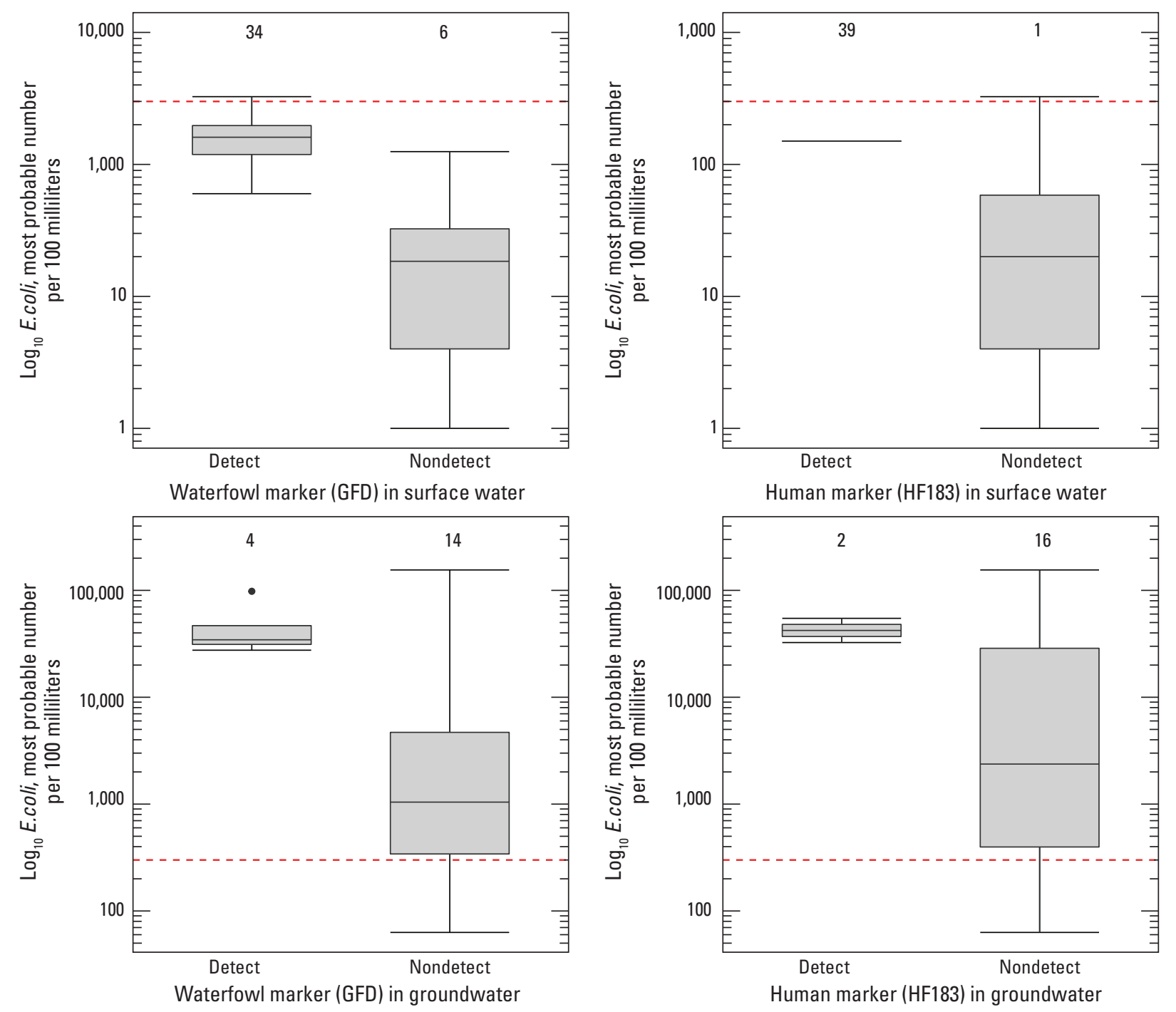

EXPLANATION

[Logarithmic scale]

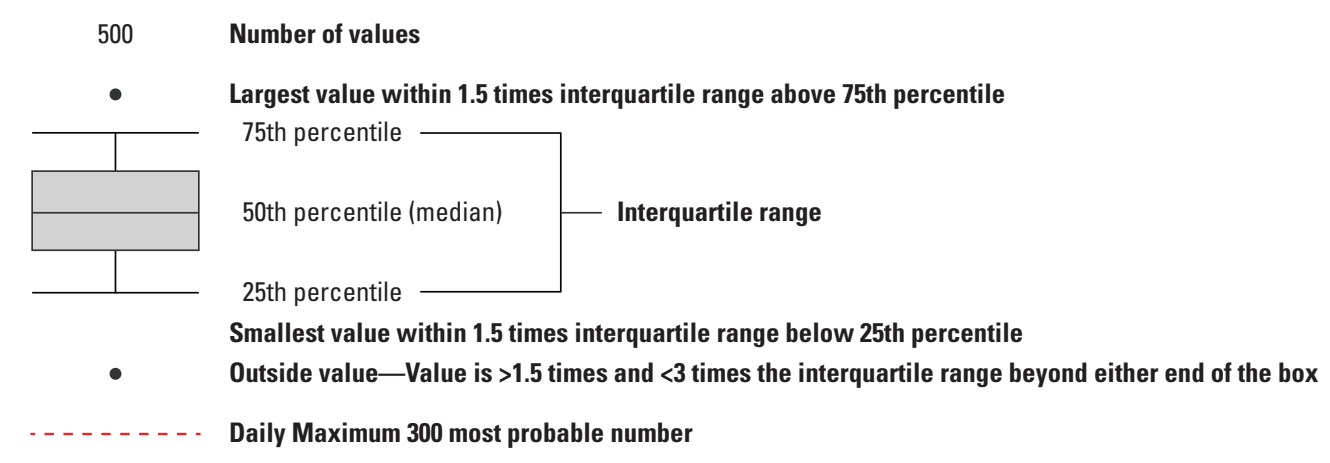

Figure 12. Escherichia coli (E. coli) concentrations of samples with detection and nondetection of waterfowl marker (GFD) in surface water and groundwater samples and human marker (HF183) in groundwater, logarithmic scale. 
the replicate samples warrant consideration when evaluating individual E. coli sample results. Conclusions drawn from this study are based on multiple lines of evidence and evaluation of results in comparable groups to reduce the inherent variability in sample collection and analysis techniques.

During the study period (2018-2019), results do not indicate that the Clinton River or other offshore areas are sources of $E$. coli to LSCMB. This assessment is supported by low to nondetectable concentrations of $E$. coli offshore and along a transect from the beach to the Clinton River. In addition, lake-bottom sediments also had low concentrations of $E$. coli and thus are an unlikely source. Results indicated it is more likely $E$. coli is coming from onshore near the swimming beach rather than from Lake St. Clair waters coming to shore. Highest $E$. coli concentrations were recorded in shallower swimming waters at the beach, shallow groundwater, and detritus sand at the beach.

Sediment and beach sand may serve as a reservoir for E. coli strains that can establish populations and intensify in quantity during peak recreation times in the summer months. E. coli concentrations exceeded $300 \mathrm{MPN} / 100 \mathrm{~mL}$ in 91 percent of the detritus and 45 percent of the surface beach sand samples. A study by Francy and Darner (1998) determined that bacteria survive longer in sediment and beach sand than water. This may be a result of available organic matter required for growth or particulates that protected from ultraviolet radiation.

Decades of beach studies have indicated that $E$. coli from multiple sources can survive and promulgate in sand then be washed into the recreational waters, elevating fecal-indicator bacteria counts (Whitman and Nevers, 2003; Byappanahalli and others, 2003; Alm and others, 2006; Ishii and others, 2007; Vogel and others, 2016; Palmer and others, 2020). The groundwater at the beach is about $2-3 \mathrm{ft}$ below land surface. E. coli may transport from the surface to groundwater during recharge after rain event or during beach grooming when surface sand is raked. E. coli could be release to nearshore surface waters by physical and hydrological processes (Francy and others, 2006; Ishii and others, 2007; Vogel and others, 2016).

This nearshore land-to-groundwater-to-lake connection can be dynamic, and it is possible there may be continuous movement of $E$. coli population from land to water. Ishii and others (2007) determined that waves can be important in the early colonization and distribution of $E$. coli in sediment and beach sand and in the release from sediment and beach sand to lake water. Their study indicated that sediment and sand were acting as sources and sinks of $E$. coli and contributing to beach closures. It is likely that there is water movement back and forth in this interphase, but the current study was not designed to address groundwater flow or lake interaction.
E. coli concentrations in the groundwater samples in this study were orders of magnitude higher than the lake water. Concentrations were highest near the lake/land interphase, which indicates groundwater could be a source of $E$. coli to the lake; however, groundwater also might be a sink for $E$. coli from the lake and stored in the shallow groundwater. As lake water moves inland, E. coli in the lake may accumulate on or in between sand particles. However, it is important to note than while concentrations were often lower upland, concentrations in the farthest upland area (farther from lake) were still commonly orders of magnitude higher than the lake water. Byappanahalli and others (2006) determined similar E. coli concentrations can persist for extended periods in backshore sand and groundwater. Interestingly, sand samples collected near the groundwater table contained very low E. coli concentrations compared to the surface and groundwater. It is possible that during rain events, $E$. coli is quickly transported through the shallow sediment into the groundwater where it can remain or be stored in sediment at the water table and released by wave actions, foreshore sand erosion, and precipitation (Beversdorf and others, 2006; Ishii and others, 2007; Malott and others, 2016; Vogel and others, 2016).

Waterfowl (in particular gulls) congregate at or near the beach and may be an originating source of $E$. coli at LSCMB. Fecal material from waterfowl may contribute to $E$. coli on the beach sand, which can then be transported into the nearshore water through wave action, runoff after rain events, wind movement, or human transfer. Fecal matter may also be transported through the sand to the shallow groundwater. However, it is still uncertain how and if this contributes to the periodic beach closures and risk to public health. The waterfowl MST marker (GFD) was detected in 15 percent of the samples at low concentrations (table 16). Most of those detections were on the beach sand, groundwater, and shallow swimming waters. There were indications that the presence of the GFD marker was related to higher $E$. coli concentrations, but the sample size was small. It is also important to note that the human (HF183) MST marker was also detected in these samples; therefore, a human fecal source cannot be ruled out.

Survival of E. coli and MST markers are often different, with MST markers being typically more representative of recent fecal contamination (Dick and others, 2010). E. coli may be introduced in the beach sand and over time become naturalized and then moved to nearshore waters via runoff, wave action, or groundwater transport (Ishii and others, 2007; Ge and others, 2012; Rumball and others, 2020). Because MST markers are different analytes from E. coli (genetic sequences from Bacteroides [HF183] and Helicobacter [GFD] spp.), different transport and survival characteristics can be expected, and thus, MST markers may not be good markers for "older," naturalized E. coli. The low concentrations of MST markers from this study might indicate that $E$. coli is 
naturalized or older, or MST markers might indicate alternative sources such as dogs or wildlife. The MST analysis in this study was limited to five sampling dates; thus, further studies with more temporal coverage would be needed to determine if $E$. coli residing on the sand or in the groundwater are from recent fecal contamination or naturalized populations. Better understanding of the fecal source and transport mechanisms would be helpful in determining how to reduce $E$. coli to prevent beach closures and in informing risk to human health.

Temporal and spatial variability of environmental factors such as temperature, wind, and precipitation affect fate and transport of fecal-indicator bacteria, and previous studies have determined positive correlations between $E$. coli concentrations and weather variables (Whitman and others, 2004; Holtschlag and others, 2008; Francy and others, 2013; Vogel and others 2016). Holtschlag and others (2008) determined that rainfall before sampling, water temperature, turbidity, water levels, and wind (directions and speed) were positively correlated with $E$. coli concentrations within a 2-day timespan of E. coli sample collection at LSCMB. Results from this study were less conclusive. There was no statistical correlation of $E$. coli concentrations to environmental variables such as temperature, wind, waves, and precipitation. This could be a result of $E$. coli concentration being variable across the sites on any sampling date. Previous studies were based on a single E. coli concentration representing the swimming waters. This study however, included samples from 15 locations around the park. On most dates, the E. coli concentrations were highly variable between sites; therefore, it is not surprising larger scale environmental properties were not correlated.

Despite a lack of correlation between E. coli concentrations and precipitation, standing water left behind after rainfall contained higher $E$. coli than most of the surface-water samples. Shallow surface-water samples had $E$. coli concentrations that were no higher after precipitation than those samples collected during dry periods. Precipitation may contribute to the movement of $E$. coli to the groundwater where the groundwater samples collected after precipitation had a higher frequency of exceeding $300 \mathrm{CFU} / 100 \mathrm{~mL}$. The sampling of groundwater was limited in this study, but groundwater, beach sand, and standing water after rain events had the highest concentrations of $E$. coli measured in this study. With a lower $E$. coli concentration offshore than in shallow swimming water and the high concentrations at the beach, it is likely the source of $E$. coli resulting in beach closures originates at the park near the beach. Nevers and others (2020) determined E. coli and MST in water represented short-term condition while the sand and sediment reflected more of a long-term (months to years) condition. MST results indicate potential for both a waterfowl and human fecal source in beach sand, groundwater, and shallow swimming waters which has been reported in similar urban beach studies (Byappanahalli and others, 2015). A better understanding of the physical and biological processes at the beach could aid in determining sources of $E$. coli that result in periodic LSCMB closures. Groundwater connection to the lake could be better understood by a series of seepage studies to measure flow direction to and from lake and groundwater. Additionally, a better temporal and spatial representation of the groundwater and sand E. coli at LSCMB could be used to inform modeling efforts to address the localized movement of $E$. coli in this system. Understanding the roles of these sources would provide a better framework for beach management practices aimed at reducing E. coli at Metropark Beach.

\section{Summary}

The objective of this study was to determine likely sources of Escherichia coli (E. coli) at Lake St. Clair Metropark Beach in Macomb County, Michigan. The study area is within the Clinton River Area of Concern with a Beneficial Use Impairment because of frequent beach closures. The U.S. Geological Survey, in cooperation with the U.S. Environmental Protection Agency, and in collaboration with the Michigan Department of the Environment, Great Lakes, and Energy, Macomb County Health Department, and Huron-Clinton Metroparks, completed a two-year study (2018-2019) that evaluated E. coli concentrations in recreational swimming water, lake water surrounding the park, offshore Lake St. Clair waters, storm water, lakebottom sediment, beach sand, stormwater, and groundwater at the beach. Results from this study indicate the source of E. coli to Lake St. Clair Metropark Beach is likely to be localized at the swimming area rather than being transported in from offshore waters. $E$. coli concentrations were highest in shallow groundwater and surface sand, with lowest concentrations occurring in offshore waters and lake bottom sediment. Potential sources include human and waterfowl at or near the beach area. Microbial source tracking analysis showed that indeed indictors of these sources could be detected but this did not consistently relate to $E$. coli concentrations. The potential of stormwater to transport $E$. coli from the beach to swimming waters could be observed from sediment wash-out areas at the beach following significant rain. Pools of water on and near the beach following rain had concentrations similar to the beach sand and groundwater, higher than the swimming waters. Though there are indications of $E$. coli sources on the land near swimming waters, it is not understood where the E.coli on land originates or how it is transported to the water resulting in beach closures. A better understanding of the transport and fate of $E$. coli in the beach sand and groundwater could aid in determining sources of $E$. coli that result in periodic closure at Lake St. Clair Metropark Beach. 


\section{References Cited}

Alm, E.W., Burke, J., and Hagan, E., 2006, Persistence and potential growth of the fecal indicator bacteria, Escherichia coli, in shoreline sand at Lake Huron: Journal of Great Lakes Research, v. 32, no. 2, p. 401-405.

Boehm, A.B., Fuhrman, J.A., Mrše, R.D., and Grant, S.B., 2003, Tiered approach for identification of a human fecal pollution source at a recreational beach-Case study at Avalon Bay, Catalina Island, California: Environmental Science \& Technology, v. 37, p. 673-680. [Also available at https://doi.org/10.1021/es025934x.].

Bustin, S.A., Benes, V., Garson, J.A., Hellemans, J., Huggett, J., Kubista, M., Mueller, R., Nolan, T., Pfaffl, M.W., Shipley, G.L., Vandesompele, J., and Wittwer, C.T., 2009, The MIQE guidelines-Minimum information for publication of quantitative real-time PCR experiments: Clinical Chemistry, v. 55, no. 4, p. 611-622. [Also available at https://doi.org/10.1373/clinchem.2008.112797.].

Beversdorf, L.J., Bornstein-Forst, S.M., and McLellan, S.L., 2006, The potential for beach sand to serve as a reservoir for Escherichia coli and the physical influences on cell die-off: Journal of Applied Microbiology, v. 102, no. 5, p. 1372-1381. [Also available at https://doi.org/10.1111/j.1365-2672.2006.03177.x.].

Byappanahalli, M., Fowler, M., Shively, D., and Whitman, R., 2003, Ubiquity and persistence of Escherichia coli in a Midwestern coastal stream: Applied and Environmental Microbiology, v. 69 , no. 8, p. 4549-4555. [Also available at https://doi.org/10.1128/AEM.69.8.4549-4555.2003.].

Byappanahalli, M.N., Whitman, R.L., Shively, D.A., Ting, W.T.E., Tseng, C.C., and Nevers, M.B., 2006, Seasonal persistence and population characteristics of Escherichia coli and enterococci in deep backshore sand of two freshwater beaches: Journal of Water and Health, v. 4, no. 3, p. 313-320.

Byappanahalli, M.N., Nevers, M.B., Whitman, R.L., Ge, Z., Shively, D., Spoljaric, A., and Przybyla-Kelly, K., 2015, Wildlife, urban inputs, and landscape configuration are responsible for degraded swimming water quality at an embayed beach: Journal of Great Lakes Research, v. 41, no. 1, p. 156-163.

Chen, H.J., and Chang, H., 2014, Response of discharge, TSS, and E. coli to rainfall events in urban, suburban, and rural watersheds: Environmental Science. Processes \& Impacts, v. 16, no. 10, p. 2313-2324. [Also available at https://doi.org/10.1039/C4EM00327F.].
Dick, L.K., Stelzer, E.A., Bertke, E.E., Fong, D.L., and Stoeckel, D.M., 2010, Relative decay of Bacteroidales microbial source tracking markers and cultivated Escherichia coli in freshwater microcosms: Applied and Environmental Microbiology, v. 76, no. 10, p. 3255-3262. [Also available at https://doi.org/10.1128/AEM.02636-09.].

Fogarty, L.R., 2007, Bacteria and emerging chemical contaminants in the St. Clair River/Lake St. Clair Basin, Michigan: U.S. Geological Survey OpenFile Report 2007-1083, 10 p. [Also available at https://doi.org/10.3133/ofr20071083.].

Francy, D.S., Struffolino, P., Brady, A.M.G., and Dwyer, D.F., 2005, A spatial, multivariable approach for identifying proximate sources of Escherichia coli to Maumee Bay, Lake Erie, Ohio: U.S. Geological Survey Open File Report 2005-1386, 20 p. [Also available at https://doi.org/10.3133/ofr20051386.].

Francy, D.S., Bertke, E.E., Finnegan, D.P., Kephart, C.M., Sheets, R.A., Rhoades, J., and Stumpe, L., 2006, Use of spatial and microbial source-tracking tools for understanding fecal contamination at two Lake Erie beaches: U.S. Geological Survey Scientific Investigations Report 2006-5298, 29 p. [Also available at https://doi.org/10.3133/sir20065298.].

Francy, D.S., and Darner, R.A., 1998, Factors affecting Escherichia coli concentrations at Lake Erie public bathing beaches: U.S. Geological Survey Water-Resources Investigations Report 98-424, 41 p. [Also available at https://doi.org/10.3133/wri984241.].

Francy, D.S., and Stelzer, E.A., 2012, Microbial source tracking markers at three inland recreational lakes in Ohio, 2011: U.S. Geological Survey Open-File Report 2012-1222, 8 p., accessed August 2020, at https://doi.org/10.3133/ ofr20121222.

Francy, D.S., Stelzer, E.A., Duris, J.W., Brady, A.M.G., Harrison, J.H., Johnson, H.E., and Ware, M.W., 2013, Predictive models for Escherichia coli concentrations at inland lake beaches and relationship of model variables to pathogen detection: Applied and Environmental Microbiology, v. 79, no. 5, p. 1676-1688. [Also available at https://doi.org/10.1128/AEM.02995-12.].

Francy, D.S., Bushon, R.N., Brady, A.M.G., Kephart, C.M., Stelzer, E.A., and Ecker, C.D., 2017, Quality assurance/quality control manual: Ohio Water Microbiology Laboratory, accessed December, 2020, at https://www .usgs.gov/centers/oki-water/science/ohio-microbiologyprogram-qaqc?qt-science_center_objects $=0 \#$ 
Ge, Z., Whitman, R.L., Nevers, M.B., Phanikumar, M.S., and Byappanahalli, M.N., 2012, Nearshore hydrodynamics as loading and forcing factors for Escherichia coli contamination at an embayed beach: Limnology and Oceanography, v. 57 , no. 1 , p. $362-381$.

Green, H.C., Dick, L.K., Gilpin, B., Samadpour, M., and Field, K.G., 2012, Genetic markers for rapid PCR-based identification of gull, Canada goose, duck, and chicken fecal contamination in water: Applied Environmental Microbiology, v. 78, no. 2, p. 503e510. [Also available at https://doi.org/10.1128/AEM.05734-11.].

Green, H.C., Haugland, R.A., Varma, M., Millen, H.T., Borchardt, M.A., Field, K.G., Walters, W.A., Knight, R., Sivaganesan, M., Kelty, C.A., and Shanks, O.C., 2014, Improved HF183 quantitative real-time PCR assay for characterization of human fecal pollution in ambient surface water samples: Applied and Environmental Microbiology, v. 80, no. 10, p. 3086-3094. [Also available at https://doi.org/10.1128/AEM.04137-13.].

Hagedorn, C., Blanch, A.R., and Harwood, V.J., eds., 2011, Microbial source tracking-Methods, applications, and case studies: New York, New York, Springer, 644 p. [Also available at https://doi.org/10.1007/978-1-4419-9386-1.].

Holtschlag, D.J., Shively, D., Whitman, R.L., Haack, S.K., and Fogarty, L.R., 2008, Environmental factors and flow paths related to Escherichia coli concentrations at two beaches on Lake St. Clair, Michigan, 2002-2005: U.S. Geological Survey Scientific Investigations Report 2008-5028, 38 p. [Also available at https://doi.org/10.3133/sir20085028.].

International Joint Commission United States and Canada, 1987, Great Lakes water quality agreement-Protocol amending the 1978 agreement between Canada and the United States of America on Great Lakes water quality, 1978, as amended on October 16, 1983: International Joint Commission United States and Canada, 75 p.

Ishii, S., Hansen, D.L., Hicks, R.E., and Sadowsky, M.J., 2007, Beach sand and sediments are temporal sinks and sources of Escherichia coli in Lake Superior: Environmental Science \& Technology, v. 41, no. 7, p. 2203-2209.

Jin, S., Homer, C., Yang, L., Danielson, P., Dewitz, J., Li, C., Zhu, Z., Xian, G., and Howard, D., 2019, Overall methodology design for the United States National Land Cover Database 2016 Products: Remote Sensing, v. 11, no. 24, p. 2971.

Macomb County Health Department, 2019, Total body contact standards: Macomb County Health Department web page, accessed May 21, 2020, at https://health.macombgov.org/ Health-Programs-EnvironmentalHealth-SurfaceWaterM onitoring-BeachMethodology
Macomb County Health Department (MCHD), 2020a, Historical beach testing data: Macomb County Health Department web page, accessed May 21, 2020, at https://health.macombgov.org/Health-ProgramsEnvironmentalHealth-BeachTestData-BeachArchiveData

Macomb County Health Department (MCHD), 2020b, Historical surface water testing data: Macomb County Health Department web page, accessed May 21, 2020, at https://health.macombgov.org/sites/default/files/content/ government/health/pdfs/surfacewater/2019SurfaceWaterS amples.pdf

Malott, S., O'Carroll, D.M., and Robinson, C.E., 2016, Dynamic groundwater flows and geochemistry in a sandy nearshore aquifer over a wave event: Water Resources Research, v. 52, no. 7, p. 5248-5264. [Also available at https://doi.org/10.1002/2015WR017537.].

Michigan Department of Environmental Quality, 2006, Water resources protection, part 4, Water quality standards: Michigan Department of Environmental Quality Water Bureau report, 72 p., accessed August 20, 2020, at https://ars.apps.lara.state.mi.us/AdminCode/DownloadAdmi nCodeFile?FileName=302_10280_AdminCode.pdf

Michigan Department of Environmental Quality, 2009, The Michigan Department of Environmental Quality Biennial Remedial Action Plan Update for the Clinton River Area of Concern: Michigan Department of Environmental Quality report, 12 p., accessed May 22, 2020, at https ://www.michigan.gov/documents/egle/wrd-aoc-rap-clinton 665206_7.pdf

Michigan Department of Environmental Quality, 2020, BeachGuard database, Lake St. Clair - H.C.M.A. - Lake St. Clair Metropark Beach: Michigan Department of Environmental Quality webpage, accessed October 14, 2020, at https://www.egle.state.mi.us/beach/BeachDetail.aspx? BeachID $=545$

Michigan Department of Natural Resources, Remedial action plan for Clinton River Area of Concern, November, 1988: Michigan Department of Natural Resources report, accessed May 22, 2020, at https://www.epa.gov/sites/production/files/ 2015-08/documents/1988_clinton_river_rap.pdf

Myers, D.N., Stoeckel, D.M., Bushon, R.N., Francy, D.S., and Brady, A.M.G., 2014, Fecal indicator bacteria: U.S. Geological Survey Techniques of Water-Resources Investigations, book 9, chap. A7.1, 73 p., accessed May 19, 2020, at https://doi.org/10.3133/twri09A7.1 
National Oceanic and Atmospheric Administration [NOAA], 2019, Huron Erie Connecting Waterways Forecasting System, HECWFS: National Oceanic Atmospheric

Administration web page, accessed August 7 and 14, 2019, at https://www.glerl.noaa.gov/res/glcfs/hecwfs/

National Oceanic and Atmospheric Administration [NOAA], 2020, Local Climatological Data for Mount Clemens ANG Base, MI US: National Oceanic and Atmospheric Administration web page, accessed May 19, 2020, at https: //www.ncdc.noaa.gov/cdo-web/datasets/LCD/stations/ WBAN:14804/detail

National Oceanic and Atmospheric Administration [NOAA], 2020b, Nation Data Buoy Center: National Oceanic and Atmospheric Administration web page, accessed May 19, 2020, at https://www.ncdc.noaa.gov/cdo-web/datasets/LCD/ stations/WBAN:14804/detail

Nevers, M.B., Byappanahalli, M.N., Nakatsu, C.H., Kinzelman, J.L., Phanikumar, M.S., Shively, D.A., and Spoljaric, A.M., 2020, Interaction of bacterial communities and indicators of water quality in shoreline sand, sediment, and water of Lake Michigan: Water Research, v. 178, p. 115671.

Palmer, J.A., Law, J.-Y., and Soupir, M.L., 2020, Spatial and temporal distribution of E. coli contamination on three inland lake and recreational beach systems in the upper Midwestern United States: The Science of the Total Environment, v. 722, accessed December 20, 2020. https:// doi.org/10.1016/j.scitotenv.2020.137846.

Rumball, N.A., Mayer, H.C., and McLellan, S.L., 2020, Selective survival of Escherichia coli phylotypes in freshwater beach sand: Applied and Environmental Microbiology, v. 87, no. 4, e02473-e20, accessed December 20, 2020. https://doi.org/10.1128/ AEM.02473-20.

U.S. Environmental Protection Agency, [EPA], 2005, Microbial source tracking guide document: U.S. Environmental Protection Agency report EPA/600/R-05/064, 123 p., accessed September 3, 2020, at https://cfpub.epa.gov/si/si_public_record_Report.cfm?Lab= NRMRL\&dirEntryID=133523
U.S. Environmental Protection Agency, [EPA], 2012, Recreational water quality criteria: U.S. Environmental Protection Agency Office of Water Report 820-F-12-058, 63 p., accessed May 22, 2020, at https://www.epa.gov/sites/ production/files/2015-10/documents/rwqc2012.pdf

U.S. Environmental Protection Agency, [EPA], 2019, EPA's Beach Report: 2018 Swimming Season: U.S. Environmental Protection Agency Report EPA 820-F-19-002, 3 p., accessed August 19, 2020, at https:/www.epa.gov/beach-tech/2018beach-swimming-season-report

U.S. Geological Survey, [USGS], variously dated, National field manual for the collection of water-quality data: U.S. Geological Survey Techniques of Water-Resources Investigations, book 9, chaps. A1-A10, accessed November 8, 2019, at https://pubs.water.usgs.gov/twri9A.

U.S. Geological Survey [USGS], 2020, USGS water data for the Nation: U.S. Geological Survey National Water Information System database, accessed May 19, 2020, at https://doi.org/10.5066/F7P55KJN.

Vogel, L.J., O’Carroll, D.M., Edge, T.A., and Robinson, C.E., 2016, Release of Escherichia coli from foreshore sand and pore water during intensified wave conditions at a recreation beach: Environmental Science \& Technology, v. 50, no. 11, p. 5676-5684. [Also available at https://doi.org/10.1021/acs.est.6b00707.].

Whitman, R.L., and Nevers, M.B., 2003, Foreshore sand as a source of Escherichia coli in nearshore water of a Lake Michigan beach: Applied and Environmental Microbiology, v. 69, no. 9, p. 5555-5562. [Also available at https://doi.org/10.1128/AEM.69.9.5555-5562.2003.].

Whitman, R.L., Nevers, M.B., Korinek, G.C., and Byappanahalli, M.N., 2004, Solar and temporal effects on Escherichia coli concentration at a Lake Michigan swimming beach: Applied and Environmental Microbiology, v. 70, no. 7, p. 4276-4285. [Also available at https://doi.org/10.1128/AEM.70.7.4276-4285.2004.].

Whitman, R.L., and Nevers, M.B., 2008, E. coli patterns and responses along 23 Chicago beaches: Environmental Science \& Technology, v. 42, no. 24, p. 9217-9224. [Also available at https://doi.org/10.1021/es8019758.]. 
For additional information contact:

Director, USGS Upper Midwest Water Science Center 5840 Enterprise Drive

Lansing, MI 48911

https://www.usgs.gov/centers/upper-midwest-water-science-center

Publishing support provided by the Indianapolis Publishing Service Center 


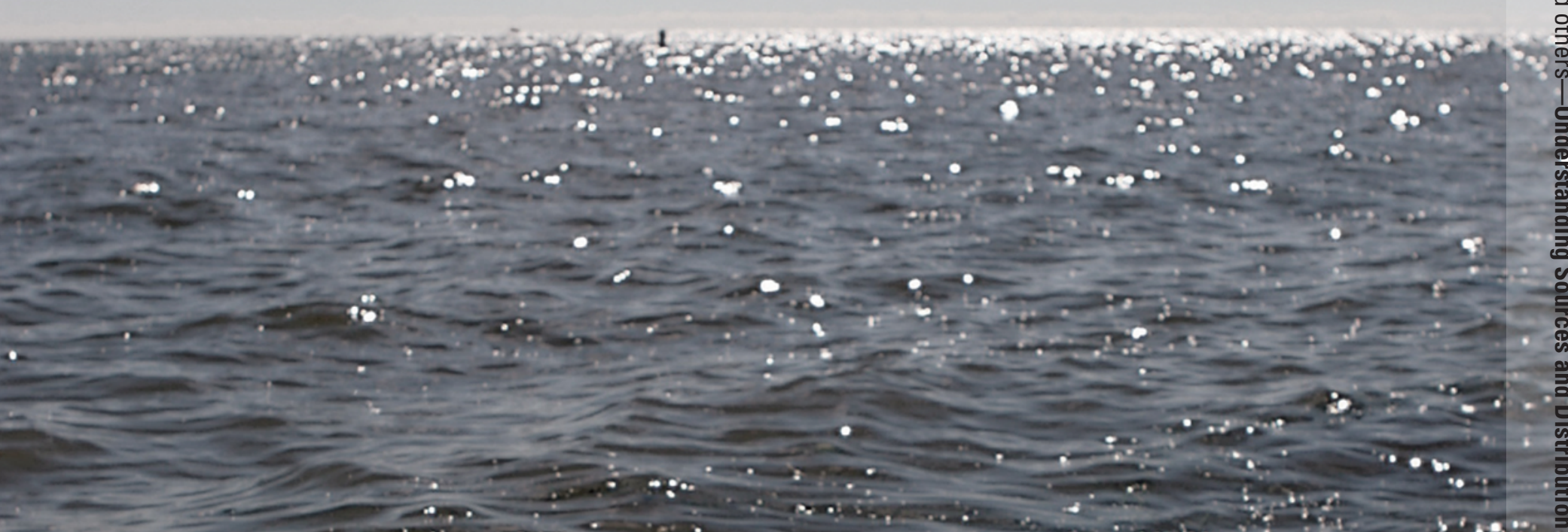

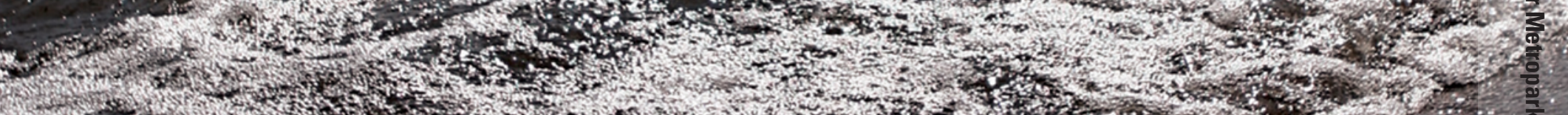

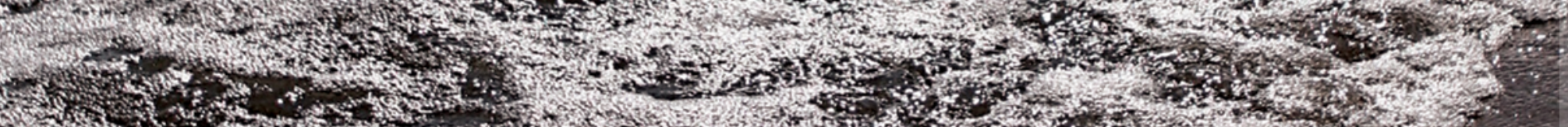
(2)

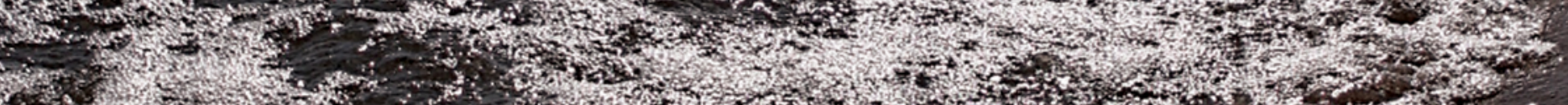

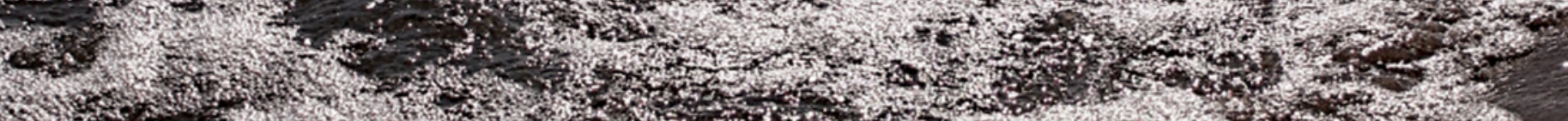
Nor.

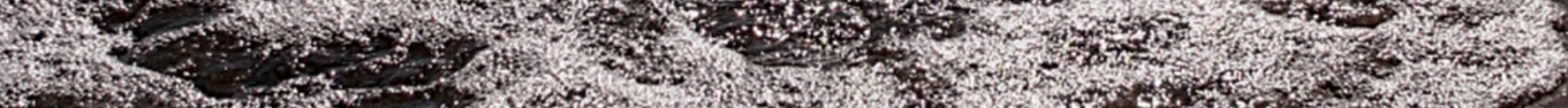
1.4.

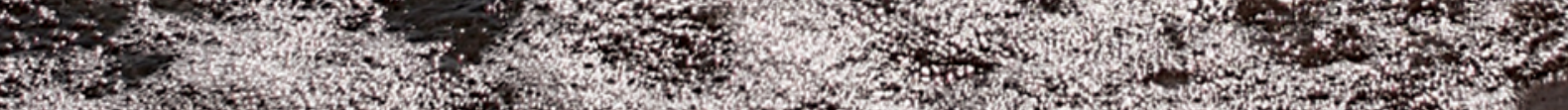

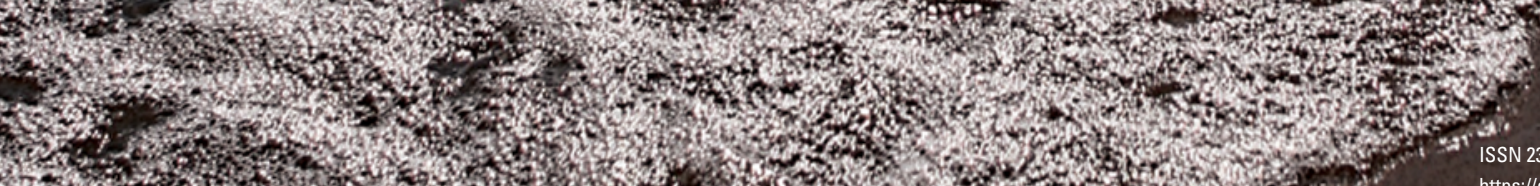

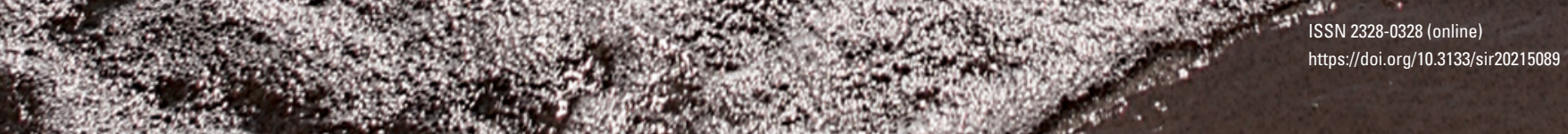
(1) 